\title{
A General Equilibrium Assessment of COVID-19's Labor Productivity Impacts on China's Regional Economies
}

\author{
Xi He, Edward J. Balistreri, Gyu Hyun Kim, Wendong Zhang
}

\author{
Working Paper 21-WP 617 \\ Updated \\ July 2022
}

\author{
Center for Agricultural and Rural Development \\ lowa State University \\ Ames, lowa 50011-1070 \\ www.card.iastate.edu
}

Xi He is Postdoctoral Research Associate, Department of Economics, lowa State University, Ames, IA 50011. E-mail: xihe@iastate.edu

Edward J. Balistreri is Associate Professor, Department of Economics, University of Nebraska, Lincoln, Lincoln, NE 68508. E-mail: edward.balistreri@unl.edu

Gyu Hyun Kim is PhD Candidate, Department of Economics, lowa State University, Ames, IA 50011. Email:gyuhyun@iastate.edu

Wendong Zhang is Assistant Professor, Department of Economics, lowa State University, Ames, IA 50011. E-mail: wdzhang@iastate.edu

This publication is available online on the CARD website: www.card.iastate.edu. Permission is granted to reproduce this information with appropriate attribution to the author and the Center for Agricultural and Rural Development, lowa State University, Ames, lowa 50011-1070.

For questions or comments about the contents of this paper, please contact Wendong Zhang, wdzhang@iastate.edu.

lowa State University does not discriminate on the basis of race, color, age, ethnicity, religion, national origin, pregnancy, sexual orientation, gender identity, genetic information, sex, marital status, disability, or status as a U.S. veteran. Inquiries regarding non-discrimination policies may be directed to Office of Equal Opportunity, 3410 Beardshear Hall, 515 Morrill Road, Ames, lowa 50011, Tel. (515) 294-7612, Hotline: (515) 294-1222, email eooffice@iastate.edu. 


\title{
A General Equilibrium Assessment of COVID-19's Labor Productivity Impacts on China's Regional Economies
}

\author{
BY $\mathrm{XI} \mathrm{HE}^{\mathrm{a}}$ \\ EDWARD J. BALISTRERI ${ }^{b}$ \\ GYU HYUN KIM ${ }^{c}$ \\ WENDONG ZHANG ${ }^{\mathrm{d}}$ e
}

Forthcoming in Journal of Productivity Analysis

\section{Acknowledgements}

The Center for Agricultural and Rural Development (CARD) at Iowa State University supported this research. The authors also gratefully acknowledge support from the USDA National Institute of Food and Agriculture Hatch Project IOWo4099 and grant 2019-67023-29414. We are also grateful to Thomas F. Rutherford for providing essential software and guidance.

\footnotetext{
a Postdoctoral Research Associate, Department of Economics and Center for Agricultural and Rural Development, Iowa State University, xi hediastate.edu

b Duane Acklie Chair of International Trade and Finance and Associate Professor, Department of Economics, the University of Nebraska-Lincoln, edward.balistreri@unl.edu

${ }^{c}$ Associate Research Fellow, Korea Energy Economics Institute, gyuhyun@keei.re.kr

d Assistant Professor, Dyson School of Applied Economics and Management, SC Johnson College of Business, Cornell University, wendongz@cornell . edu

e Associate Professor, Department of Economics and Center for Agricultural and Rural Development, Iowa State University, wdzhang@iastate.edu
} 
This study introduces a database for analyzing COVID-19's impacts on China's regional economies. This database contains various sectoral and regional economic outcomes at the weekly and monthly level. In the context of a general equilibrium trade model, we first formulate a mathematical representation of the Chinese regional economy and calibrate the model with China's multi-regional input-output table. We then utilize the monthly provincial and sectoral value-added and national trade series to estimate COVID-19's province-by-month labor-productivity impacts from February 2020 to September 2020. As a year-on-year comparison, relative to February 2019 levels, we find an average 39.5\% decrease in labor productivity (equivalent to around 305 million jobs) and an average $25.9 \%$ decrease in welfare. Labor productivity and welfare quickly returned to the recent high-growth trends for China in the latter half of 2020. By September 2020, relative to September 2019, average labor productivity increased by $12.2 \%$ (equivalent to around 94 million jobs) and average welfare increased by $8.2 \%$.

JEL codes: Jo1, E20, F10, R13

Keywords: COVID-19, China's regional economies, computable general equilibrium (CGE), labor productivity, welfare analysis

\section{Introduction}

In late 2019, the COVID-19 pandemic started in Hubei, China. The pandemic quickly spread to other countries over the first several months of 2020 causing significant global economic and social costs. According to the International Monetary Fund, global gross domestic product (GDP) decreased by 3.5\% in 2020 compared to 2019, with a decrease of $4.9 \%$ for advanced economies and a decrease of $2.4 \%$ for emerging markets and developing economies. China was the only major economy reporting an economic expansion, with a growth rate of $2.3 \%$ (IMF 2021). During the early stages of the pandemic, China took strict lockdown and quarantine measures, then gradually loosened mobility restrictions and resumed economic activities in late March (Fang et al. 2020). China's negative year-on-year GDP growth rate of $-6.8 \%$ in the first quarter of 2020 reflects the significant economic costs associated with the stagnation of economic activities. According to the Chinese National Bureau of Statistics (CNBS), since April 2020, China's economy has gradually recovered with year-on-year GDP growth rates of $3.2 \%, 4.9 \%$, and $6.5 \%$ in the second, third, and fourth quarters of 2020, respectively (CNBS 2020). The spread of COVID-19 in other economies also significantly affected China's economy via trade links formed during the past decades of globalization. In the first quarter of 2020, while China's goods export value fell by $11.4 \%$ compared with the first quarter of 2019, year-on-year exports increased by $4.5 \%, 10.2 \%$, and $4.0 \%$ in the second, third, and fourth quarters, respectively. The export growth reflects both China's productivity recovery and other countries' production and 
distribution capabilities contraction, which helped create favorable conditions for China's exports.

National economic outcomes, however, cannot capture the uneven impacts of COVID-19 across China's regions and sectors. This heterogeneity is not only rooted in the regional disparities in economic development levels and reliance on exports, but also caused by COVID-19's spatial propagation patterns and the varying stringency of control measures across China. Understanding how COVID-19 affects China's regional economies is important for designing and evaluating relevant economic recovery policies. While CNBS publishes the value-added growth rate of sectors and provinces on a monthly basis, it does not publish province-level labor statistics on a monthly basis. Due to the complex input-output linkages across sectors and provinces, regional and sectoral labor productivity changes affect regional and sectoral value-added via the production networks reflected by the multi-regional input-output (MRIO) table. Given that regional labor estimates are an important basis of regional recovery and support strategies, we aim to quantify the implied monthly regional labor productivity and welfare impacts embedded in the value-added statistics. Our estimates are useful to policy makers because they can be used to translate COVID-19 responses into familiar metrics for assessing economic costs - job equivalents and money-metric welfare (equivalent variation).

We first introduce a subnational database, the CARD COVID-19 Economic Database: China, developed by the Center for Agricultural and Rural Development (CARD) at Iowa State University, which contains various regional and sectoral economic outcomes (He et al. 2020). Researchers can use the database to assess COVID19 's impacts on China's national and subnational economy. We then use a computable general equilibrium (CGE) model that accounts for extensive sectoral and regional economic linkages in China to quantify the regional implied labor productivity shocks that best fit the observed changes in monthly provincial and sectoral value-added and national trade series. Specifically, we use a comparative static model calibrated to a 30 provinces by 30 sectors MRIO table developed by Mi et al. (2018). ${ }^{1}$ This MRIO table provides inter-provincial and inter-sectoral economic flows among 30 economic sectors in China's 30 provinces in 2012. This is the first MRIO table to reflect China's economic development pattern after the 2008 global financial crisis (Mi et al. 2018). The MRIO table accounts for complicated input-output linkages between sectors across provinces and can capture the production network and key technology differences across geography.

We use a structural model to quantify the implied monthly provincial labor productivity and welfare impacts that are consistent with observed provincial and sectoral output changes. ${ }^{2}$ We run the model with and without incorporat-

\footnotetext{
${ }^{1}$ Note that the subnational MRIO table compiled by Mi et al. (2018) does not include Tibet, Hong Kong, Macau, and Taiwan.

${ }^{2}$ We only consider differential sectoral shocks for the manufacturing sectors, which we
} 
ing shocks that target observed national imports and exports. This yields two sets of implied labor productivity and welfare estimates. ${ }^{3}$ While the structural model does not distinguish between provincial labor productivity or employment shocks, we can use information on wage bills to back out a jobs equivalent. The comparison of the results with and without trade targeting provides insights on how global pandemic responses impact China's recovery from the COVID-19 pandemic.

Our main results show that the COVID-19 pandemic had substantial yet shortlived impacts on labor productivity across Chinese provinces, especially in the epicenter, Hubei Province. Across provinces, when we do not consider trade shocks, average year-on-year labor productivity fell by $37.9 \%$ and average welfare fell by $20.8 \%$ in February 2020. The $37.9 \%$ decrease in labor productivity is equal to 293 million jobs based on an employment of 774 million in 2019. In Hubei, year-onyear labor productivity fell by 74.1\% (26.3 million job equivalent) in February 2020. Our estimated productivity shocks are for the aggregate provincial labor force and do not differentiate losses of employment, reductions in working hours, or other sources of productivity adjustments. We report these as losses in the productive capacity of the labor force or as full-time equivalent (FTE) jobs, which is a useful and familiar metric for assessing labor market shocks.

Labor productivity and welfare recovered quickly in 2020. By September 2020, relative to September 2019, average labor productivity increased by $29.8 \%$ (230 million job equivalent) and average welfare increased by $14.7 \%$ across all provinces. This year-on-year productivity growth is high even for a fast growing country like China. This prediction moderates substantially when we consider COVID19 related trade shocks, as described below. Focusing on Hubei Province, the year-on-year labor productivity increase is $19.4 \%$ (6.9 million job equivalent) as of September 2020. In addition, we find significantly heterogeneous recovery patterns across regions. Specifically, provinces in eastern China recovered the fastest, from a population-weighted average year-on-year labor-productivity shock of $45.1 \%$ in February to $+39.2 \%$ in September 2020 . The labor productivity recovery in northwestern China is more modest and increased from a negative shock of $-23.3 \%$ in February to $+23.3 \%$ in September 2020. These estimates rely on endogenous trade responses native to the model formulation of China as a large open economy. We postulate, however, in a set of follow-up estimates that COVID-19 included substantial shifts in China's export-demand and import-supply schedules. We guide these trade shocks using observed changes in aggregate imports and exports.

include in the value-added data sources. For other sectors (agriculture and services) we only consider the aggregate provincial shock to labor.

3 Given that CNBS publishes sector- and province-level value-added changes compared with the previous year, our labor productivity estimates are also a series of annual calculations compared with the same month in the prior year. 
The patterns of the pandemic's spatial and temporal impacts on labor productivity are similar across treatments, with and without trade shocks, but there are some important differences to highlight. Labor productivity estimates grew faster in April-June and grew slower in August and September 2020 when we consider national trade shocks. Specifically, with trade shocks included, a year-on-year comparison for February indicates an average 39.5\% decrease in labor productivity (equivalent to around 305 million jobs) and an average $25.9 \%$ decrease in welfare. These are only slightly larger than when we do not include trade shocks, but the trade shocks become more important in the recovery period. For September 2020, relative to September 2019, average labor productivity increased by $12.2 \%$ (equivalent to around 94 million jobs) and average welfare increased by $8.2 \%$. These are much lower than the estimates under no trade shocks. An explanation for this difference is that China's net-export demand increased significanlty after July. To accommodate the observed income growth accounting for the trade shocks means that less burden is placed on productivity. Therefore, the models without national trade shocks slightly underestimates the labor productivity shocks from AprilJune, but substantially overestimates the labor productivity increases in August and September.

This study relates to and contributes to three strands of literature. First, this paper contributes to a line of literature that uses general equilibrium models to investigate COVID-19's impacts in different countries, including the United States (Walmsley et al. 2021), China (Zhao 2020), the UK (Keogh-Brown et al. 2020), India (Sahoo and Ashwani 2020), and Brazil (Porsse et al. 2020). The unique contribution of this paper is that we conduct the analysis at the province level and we are able to quantify the labor productivity impacts at the province-by-month level, while most studies are at the national and annual level (McKibbin and Fernando 2020; Maliszewska et al. 2020; Zhang et al. 2020; Zhao 2020; Keogh-Brown et al. 2020; Sahoo and Ashwani 2020). For example, Maliszewska et al. (2020) simulate the impacts of a global pandemic using Envisage (a well documented CGE model) calibrated to GTAP 10 accounts and find global GDP decreased by $2.0 \%$ in a full global pandemic and decreased by $4.0 \%$ in an amplified global pandemic. Similarly, Zhang et al. (2020) utilize an economy-wide multi-sector multiplier model built on China's 2017 social accounting matrix with 147 economic sectors to assess COVID-19's impacts on China's macroeconomy and find that China's economy will grow less than $1.0 \%$ in 2020 without resumed export demand and $1.7 \%$ with resumed export demand. Notable exceptions that use subnational CGE models to investigate COVID-19's impacts are Porsse et al. (2020) and Modrego et al. (2020). Porsse et al. (2020) use a dynamic inter-regional CGE model to project COVID-19's economic impacts in Brazil. Modrego et al. (2020) estimate COVID19's regional employment effects across Chile's regions. Considering COVID-19's impacts could be quite heterogenous across subnational regions and the paucity of regional data suitable for CGE modeling has long been a constraint (Giesecke 
and Madden 2013), the subnational labor productivity estimates provided in this paper are important to inform regional recovery and support strategies.

Second, this paper introduces two complete datasets of COVID-19's estimated impacts on China's province-by-month labor productivity. These estimates are useful for future academic and health-policy analysis. In this way, this paper contributes to the broader literature on COVID-19's impacts on regional employment and economic outcomes (Barwick et al. 2020; Bartik et al. 2020; Forsythe et al. 2020; Bottan et al. 2020). Barwick et al. (2020) use mobile phone records for 71 million users and a difference-in-differences (DID) framework to study the COVID-19 pandemic's labor market impacts in Guangdong, China and find that the pandemic increased unemployment by $27 \%-62 \%$ from late January to the end of September 2020. Reduced-form analysis is the basis of most studies on COVID19's labor market impacts, which could neglect the feedback effects by broader supply and demand factors. Our paper contributes by utilizing a CGE modeling framework that accounts for broad linkage between regions and sectors.

Third, while researchers often use CGE models to simulate the impact of actual or hypothetical policies (Giesecke and Madden 2013), we use our model to uncover unobserved implied shocks that are consistent with observables as in Bauer et al. (2005) and Monte et al. (2018). Specifically, Monte et al. (2018) use a general equilibrium model to recover unique values of the unobserved productivity and amenities fundamentals that rationalize observed wages, employment, commuting flows, and land area. Dixon and Rimmer (1998) and Dixon and Rimmer (2002) also apply similar methods for accurate forecasting and policy analysis in the context of a dynamic model of Australia. We contribute to the CGE modeling literature by providing an example of utilizing observed output and trade data to uncover unobserved labor productivity shocks. This is especially useful when subnational labor statistics are not collected or reported in a timely manner. Considering some important regional labor statistics are often non-existent or outdated in developing countries, future studies can follow this method and use observed output and trade data to back out labor statistics not reported in a timely manner.

The rest of the paper proceeds as follows. Section two offers a description of the database and the value-added and trade data used in the analysis. Section three describes the general equilibrium modeling structure. Section four presents the labor productivity and welfare estimates. Section five discusses the limitations of the model and potential future extensions.

\section{Data}

\subsection{CARD COVID-19 Economic Database: China}

He et al. (2020) developed the CARD COVID-19 Economic Database: China to track COVID-19's evolving impacts on China's regional economy and to facilitate 
research on COVID-19's global impact via economic linkages between China and the rest of the world. This database was first released in April 2020 and updated monthly through September 2020.4 There are 45 tables in the database. Table 1 describes the main data categories in the database: sectoral level data using China's IO (input-output) classification;' sectoral level data using GTAP classification; provincial data; province-by-IO sectoral data; province-by-GTAP sectoral data; provincial and sectoral GDP; monthly agricultural trade; timing of prevention and control measures; and raw datasets. We collect these data from various sources, including, but not limited to, CNBS, various provincial bureaus of statistics, China's Ministry of Agricultural and Rural Affairs, the Global Agricultural Trade System at the U.S. Department of Agriculture (USDA), and USDA's weekly agricultural export query system. We update the data on a quarterly, monthly, bi-weekly, or weekly basis.

Given the necessity of converting the sectoral GB (Guobiao) data into IO or GTAP sectoral data that we can use in GTAP and regional equilibrium modeling, He et al. (2020) develops crosswalks between GB and IO, and GB and GTAP sectors. ${ }^{6}$ He et al. (2020) also obtain the IO and sectoral GTAP data by concording the GB sectoral data reported by CNBS with the crosswalks between different classifications. The main sectoral and provincial outcomes are the monthly growth rate of value-added and fixed capital investment.7 In addition to monthly data in 2020, He et al. (2020) collect data in November and December 2019 as reference points.

4 This database is publicly available at https://www.card.iastate.edu/china/covid-19/.

5 The 30 IO sectors correspond to the 30 input-output sectors in the MRIO table in Mi et al. (2018).

${ }^{6} \mathrm{~GB}$ (Guobiao) is short for GB/T 4754-2017, which is China's industrial classification for national economic activities. Readers can access this industrial classification at http:// www.stats.gov.cn/tjsj/tjbz/201709/t20170929_1539288.html.

7 We compare growth rate with the levels in the same month of the previous year. For example, the growth rate of value-added in February 2020 was the growth of value-added in February 2020 compared with that in February 2019. 
Table 1. Data categories in CARD COVID-19 Economic Database: China

\begin{tabular}{|c|c|c|c|c|c|}
\hline Number & Category & Classification & Variables & Frequency & \\
\hline \multirow[t]{2}{*}{$1-4$} & Sectoral data & China IO & $\begin{array}{l}\text { Value-added growth rate (manufacturing sectors } \\
\text { only); Fixed capital investment growth rate }\end{array}$ & Monthly & \\
\hline & & GTAP & Same as above & Monthly & \\
\hline $5-9$ & Provincial data & $\mathrm{N} / \mathrm{A}$ & $\begin{array}{l}\text { Value-added growth rate (manufacturing sectors } \\
\text { only); Fixed capital investment growth rate; Baidu } \\
\text { Huiyan Provincial Resumption Index; Firm and la- } \\
\text { bor resumption data (for enterprises above a desig- } \\
\text { nated size) }\end{array}$ & $\begin{array}{l}\text { Monthly, } \\
\text { bi-weekly }\end{array}$ & weekly, \\
\hline \multirow[t]{2}{*}{$10-13$} & Province-by-sector data & China IO & $\begin{array}{l}\text { Value-added growth rate (manufacturing sectors } \\
\text { only); Fixed capital investment growth rate }\end{array}$ & Monthly & \\
\hline & & GTAP & Same as above & Monthly & \\
\hline $14-18$ & $\begin{array}{l}\text { Concordance and sector } \\
\text { classifications }\end{array}$ & $\mathrm{N} / \mathrm{A}$ & Concordance between IO, GB, and GTAP sectors & $\mathrm{N} / \mathrm{A}$ & \\
\hline $19-35$ & Raw datasets & & Various datasets used to generate the database & $\begin{array}{l}\text { Quarterly, } \\
\text { monthly, } \\
\text { bi-weekly }\end{array}$ & weekly, \\
\hline $36-37$ & $\begin{array}{l}\text { Industry and provincial } \\
\text { GDP }\end{array}$ & & $\begin{array}{l}\text { Quarterly cumulative GDP (100 million RMB), } \\
\text { Provincial cumulative GDP (100 million RMB) }\end{array}$ & Quarterly & \\
\hline $38-43$ & Agricultural trade & & $\begin{array}{l}\text { China's monthly agricultural import/export quan- } \\
\text { tity/value; U.S. monthly agricultural exports to } \\
\text { China; U.S. weekly key agricultural commodities } \\
\text { exports to China }\end{array}$ & Monthly & \\
\hline 44 & $\begin{array}{l}\text { Timing of prevention and } \\
\text { control measures }\end{array}$ & & $\begin{array}{l}\text { Levels of prevention and control measures in dif- } \\
\text { ferent cities }\end{array}$ & & \\
\hline 45 & Aggregate trade shocks & & $\begin{array}{l}\text { National-level growth rate of total imports and ex- } \\
\text { ports }\end{array}$ & Monthly & \\
\hline
\end{tabular}

Note: This table presents the main data categories in CARD COVID-19 Economic Database: China available at https://www.card.iastate.edu/china/covid-19/. The number denotes the order of tables in the database. 


\subsection{Provincial and sectoral value-added growth rate and national trade shocks}

The outcomes utilized in the CGE modeling are province- and sector-by-month growth rate of value-added and trade flows from Tables 1, 4, and 45 in the CARD database. While some datasets track labor shocks, like the Baidu resumption index based on mobile phone usage, there are no systematic labor productivity shocks available. We are interested in the implied labor productivity shocks and welfare impacts reflected by the observed output growth rate and trade flows. Therefore, we use the monthly growth rate of provincial and sectoral value-added and national export and import data from November 2019 to September 2020 as output targets in the CGE modeling.

Table 2 presents the year-on-year growth rate of value-added in five typical provinces-Beijing, Hubei, Zhejiang, Xinjiang, and Heilongjiang-and six administrative regions, as well as the national growth rate of export and import values. ${ }^{8}$ We select these five provinces because of their differing COVID-19 outbreak timing and lockdown measures as well as heterogeneity in economic reliance on manufacturing and trade. All five provinces are representative of the recovery in China's different regions. Figure A.I in the Appendix shows China's provinces and regions. Table 2 shows Hubei's year-on-year value-added reduced by $46.2 \%$ and $46.9 \%$ in February and March 2020, respectively, compared to 2019 levels. In February, Xinjiang's value-added reduced $0.7 \%$; however, it recovered in March 2020. Across regions, provinces in south-central China, where Hubei is located, experienced the largest drop in value-added, while provinces in northwestern China were least affected in terms of value-added. This geographical pattern is consistent with the spread of COVID-19 in China-the pandemic affected Hubei first and most and affected northwestern provinces the least.

In 2020, China's exports also suffered severe reductions of $17.2 \%$ in February and $6.6 \%$ in March. However, exports have significantly increased since June, and reached a year-on-year growth rate of $9.9 \%$ in September. The large export increase since June was partially caused by China's production increase and other countries' constrained supply capacities as they were gradually affected by the pandemic (IMF 2021). While China's imports in 2020 fell by only $4.0 \%$ and $1.0 \%$ in February and March compared with their levels in the same month in 2019, respectively, they fell sharply by $14.2 \%$ and $16.7 \%$ in April and May compared with their levels in the same month in 2019, and gradually returned to the recent high-growth trends for China in the latter half of 2020.

${ }^{8}$ Please note that value-added data do not include smaller firms and are only for enterprises with annual revenue above 20 million RMB. 
Table 2. Observed year-on-year monthly growth rate of provincial value-added and national trade flows (\%)

\begin{tabular}{|c|c|c|c|c|c|c|c|c|c|c|}
\hline & Nov 19 & Dec 19 & Feb 20 & Mar 20 & Apr 20 & May 20 & Jun 20 & Jul 20 & Aug 20 & Sep 20 \\
\hline \multicolumn{11}{|l|}{ Panel A: Growth rate of value-added (\%) } \\
\hline Beijing (BJ) & 2.5 & 4.8 & -16.2 & -13.0 & 4.8 & $5 \cdot 3$ & 10.8 & 8.8 & $5 \cdot 9$ & 5.4 \\
\hline Hubei (HB) & 6.2 & 7.8 & -46.2 & -46.9 & -2.4 & 2.0 & 2.0 & 2.2 & 4.9 & 6.2 \\
\hline Heilongjiang (HL) & -1.6 & $7 \cdot 7$ & -10.9 & $-5 \cdot 5$ & 2.9 & 0.3 & -0.5 & -1.9 & 8.5 & 9.0 \\
\hline Zhejiang (ZJ) & 9.0 & 9.8 & -18.5 & 1.3 & $9 \cdot 5$ & 9.9 & 6.5 & 6.1 & 9.9 & 10.7 \\
\hline Xinjiang (XJ) & 2.8 & 1.6 & -0.7 & 7.2 & 7.0 & 9.6 & 12.2 & 4.8 & 2.7 & 11.2 \\
\hline $\begin{array}{l}\text { North (5 provinces) } \\
\text { Beijing, Tianjin, Hebei, Shanxi, inner Mongolia }\end{array}$ & 3.8 & 3.8 & -11.6 & $-3 \cdot 4$ & 2.3 & $3 \cdot 5$ & $5 \cdot 0$ & $5 \cdot 4$ & $7 \cdot 1$ & 6.4 \\
\hline $\begin{array}{l}\text { Northeast ( } 3 \text { provinces) } \\
\text { Liaoning, Jilin, Heilongjiang }\end{array}$ & 6.8 & 10.3 & $-13 \cdot 5$ & -6.1 & 3.1 & 6.9 & $7 \cdot 3$ & 3.6 & 11.6 & $7 \cdot 9$ \\
\hline $\begin{array}{l}\text { East (7 provinces) } \\
\text { Shanghai, Jiangsu, Zhejiang, Anhui, Fujian, Jiangxi, Sh }\end{array}$ & $\begin{array}{c}7 \cdot 0 \\
\text { dong }\end{array}$ & 8.4 & $-15 \cdot 3$ & 1.8 & 6.4 & 6.2 & 6.7 & 6.4 & 8.6 & $7 \cdot 5$ \\
\hline $\begin{array}{l}\text { South-central (6 provinces) } \\
\text { Henan, Hubei, Hunan, Guandong, Guangxi, Hainan }\end{array}$ & 7.2 & $7 \cdot 5$ & -18.9 & -8.6 & 1.5 & 1.7 & 2.1 & 3.6 & 4.6 & 3.8 \\
\hline $\begin{array}{l}\text { Southwest (4 provinces) } \\
\text { Chongqing, Sichuan, Guizhou, Yunnan }\end{array}$ & $3 \cdot 4$ & $5 \cdot 3$ & -13.5 & 6.1 & $4 \cdot 3$ & 8.2 & 8.2 & 7.8 & $7 \cdot 5$ & $7 \cdot 5$ \\
\hline $\begin{array}{l}\text { Northwest ( } 5 \text { provinces) } \\
\text { Shaanxi, Gansu, Qinghai, Ningxia, Xinjiang }\end{array}$ & $7 \cdot 7$ & 8.9 & $-4 \cdot 4$ & 4.6 & 6.5 & 8.3 & 6.8 & 0.9 & 5.6 & 6.1 \\
\hline
\end{tabular}

\section{Panel B: Growth rate of trade value (\%)}

\begin{tabular}{|c|c|c|c|c|c|c|c|c|c|c|}
\hline Imports & 0.8 & 16.5 & -4.0 & -1.0 & -14.2 & -16.7 & 2.7 & -1.4 & -2.1 & 13.2 \\
\hline Exports & -1.3 & 7.9 & -17.2 & -6.6 & $3 \cdot 5$ & $-3 \cdot 3$ & 0.5 & 7.2 & $9 \cdot 5$ & 9.9 \\
\hline
\end{tabular}

Note: This table shows year-on-year value-added growth rate in five provinces and six regions and China's national trade value growth rate. Average growth rate in each region is the simple average of growth rate in all provinces in that region. 
Figure 1 shows the COVID-19 pandemic's shocks on year-on-year value-added growth rates of selected sectors. The average value-added across all sectors decreased by $18.4 \%$ in February and gradually returned to a growth rate of $5.0 \%$ in September 2020. WAP (Clothing, leather, fur, etc.) grew slowest while EEQ (Electrical-Electronic equipment) grew fastest. Given that WAP closely relates to TEX (Textile) and TEX grew faster than WAP, we modify the value-added growth rate of WAP with the combination of average growth rate across all sectors and the growth rate of TEX. Similarly, given EEQ closely relates to TEQ (Transportation sector), we modify the value-added growth rate of EEQ with the combination of average growth rate across all sectors and the growth rate of TEQ. Table 3 presents the actual sectoral shocks we use in our modeling. For WAP and EEQ, the values in bold are the actual shocks used, and values in brackets are the raw data in the CARD database. Note that for several sectoral shocks, we cannot find a reasonable value and omit them in the modeling (labeled as "-" in Table 3).

Similar to how Barrot et al. (2021) and Dingel and Neiman (2020) find that the impacts of COVID are different across sectors, we find the large variation in valueadded growth rate across sectors reflects the large variation of labor productivity changes across sectors in China. 


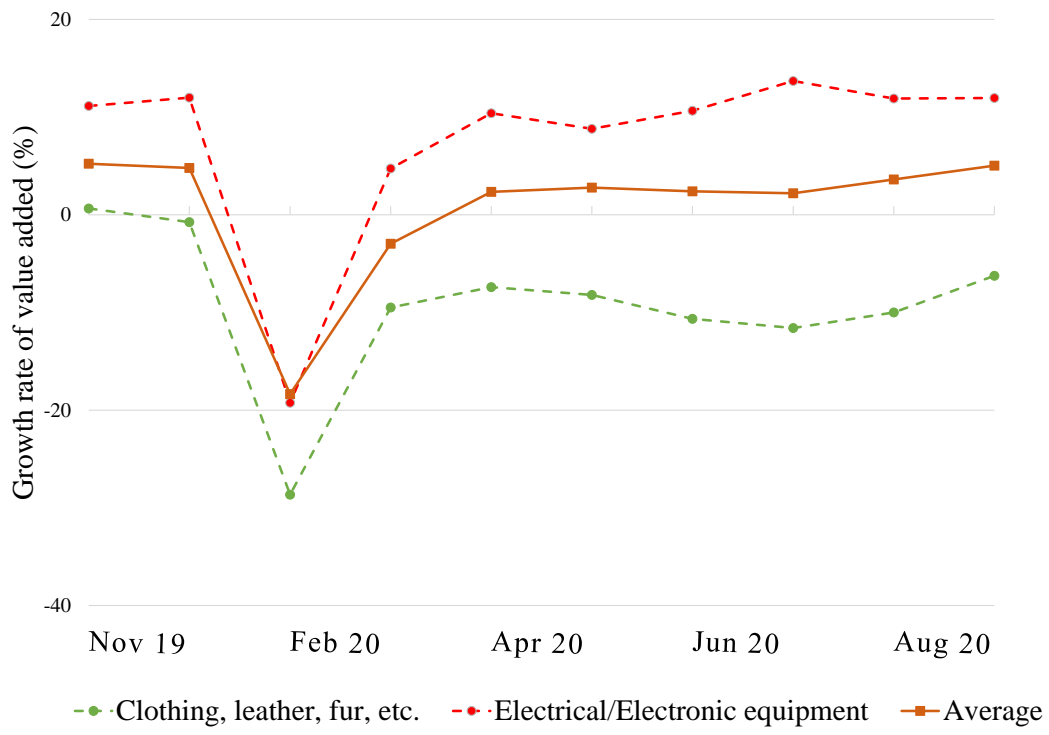

Figure 1. Value-added growth rate of China's manufacturing sectors

Note: See Table 3 for sector descriptions. We only include manufacturing sectors. Based on authors' compilation from China's National Bureau of Statistics and concordance between IO sectors and industrial sectors in the industrial classification for national economic activities in GB/T 4754-2011. 
Table 3. Observed year-on-year monthly value-added growth rate of China's manufacturing sectors (\%)

\begin{tabular}{|c|c|c|c|c|c|c|c|c|c|c|c|}
\hline Sectors & Abbr. & Nov 19 & Dec 19 & Feb 20 & Mar 20 & Apr 20 & May 20 & Jun 20 & Jul 20 & Aug 20 & Sep 20 \\
\hline 2. Coal mining & COL & 7.2 & 9.2 & -8.2 & 9.1 & $3 \cdot 7$ & 0.3 & -0.3 & -4.0 & 2.8 & 2.7 \\
\hline 3. Petroleum and gas & CRU & $3 \cdot 3$ & 2.8 & 2.1 & -1.3 & -6.2 & $3 \cdot 4$ & 8.1 & 0.2 & 2.9 & $3 \cdot 5$ \\
\hline $\begin{array}{l}\text { 4/5. Metal mining - Non- } \\
\text { metal mining }\end{array}$ & $\mathrm{OXT}$ & 1.2 & 6.5 & $-25 \cdot 5$ & -6.3 & $5 \cdot 5$ & 4.0 & 2.5 & -0.3 & $3 \cdot 7$ & $3 \cdot 9$ \\
\hline $\begin{array}{l}\text { 6. Food processing and to- } \\
\text { baccos }\end{array}$ & $\mathrm{FOO}$ & -0.9 & 4.8 & -12.7 & $3 \cdot 7$ & 1.9 & 0.7 & 0.5 & 0.03 & $-1 \cdot 3$ & 3.8 \\
\hline 7. Textile & TEX & 2.5 & 0.2 & -20.0 & $-5 \cdot 5$ & 2.0 & $4 \cdot 3$ & 3.2 & 0.7 & $3 \cdot 3$ & 5.6 \\
\hline 8. Clothing, leather, fur, etc. & WAP & $\begin{array}{l}2.5^{*} \\
(0.7)\end{array}$ & $\begin{array}{l}-* \\
(-0.8)\end{array}$ & $\begin{array}{l}-12.9^{*} \\
(-28.7)\end{array}$ & $\begin{array}{l}-3 \cdot 1^{*} \\
(-9 \cdot 5)\end{array}$ & $-7 \cdot 4$ & -8.2 & $\begin{array}{c}-* \\
(-10.7)\end{array}$ & $\begin{array}{c}-* \\
(-11.6)\end{array}$ & $\begin{array}{l}3 \cdot 7^{*} \\
(-10)\end{array}$ & $\begin{array}{l}5 \cdot 6^{*} \\
(-6 \cdot 3)\end{array}$ \\
\hline $\begin{array}{l}\text { 9. Wood processing and fur- } \\
\text { nishing }\end{array}$ & LUM & 2.6 & 3.8 & -26.0 & $-4 \cdot 7$ & $-3 \cdot 2$ & -3.6 & $-4 \cdot 9$ & -2.6 & -0.5 & 2.5 \\
\hline $\begin{array}{l}\text { 10. Paper making, printing, } \\
\text { stationery, etc. }\end{array}$ & PPP & 2.0 & 1.7 & $-25 \cdot 7$ & $-4 \cdot 7$ & 1.0 & -2.1 & -3.1 & -1.4 & 0.9 & 4.0 \\
\hline $\begin{array}{l}\text { 11. Petroleum refining, cok- } \\
\text { ing, etc. }\end{array}$ & OIL & 9.0 & $7 \cdot 3$ & -7.8 & -8.9 & -0.4 & 7.8 & 7.1 & $3 \cdot 9$ & 6.8 & 2.6 \\
\hline 12. Chemical industry & $\mathrm{CHM}$ & 7.6 & 6.6 & -15.1 & 1.0 & $3 \cdot 4$ & $3 \cdot 4$ & 4.2 & $3 \cdot 3$ & $4 \cdot 5$ & 6.9 \\
\hline 13. Nonmetal products & NMM & 8.6 & 8.4 & -21.1 & $-4 \cdot 5$ & 4.2 & $5 \cdot 5$ & 4.8 & 3.1 & 5.0 & 9.0 \\
\hline 14. Metallurgy & MET & 8.6 & $7 \cdot 9$ & $-5 \cdot 3$ & $3 \cdot 5$ & 5.8 & 5.1 & 4.6 & $5 \cdot 3$ & 7.0 & 6.3 \\
\hline $\begin{array}{l}\text { 15/16. Metal products- } \\
\text { General and specialist ma- } \\
\text { chinery }\end{array}$ & FMP & 6.3 & 6.0 & -26.6 & -2.7 & $9 \cdot 9$ & $7 \cdot 7$ & 5.6 & 8.9 & $9 \cdot 7$ & 11.4 \\
\hline 17. Transport equipment & TEQ & $3 \cdot 9$ & 1.8 & -30.0 & -11.0 & 5.8 & $7 \cdot 4$ & 6.1 & 10.1 & $7 \cdot 3$ & 10.2 \\
\hline 18/19. Electrical-Electronic & EEQ & $3 \cdot 9^{*}$ & $1.8^{*}$ & $-30.0^{*}$ & $-^{*}$ & 10.4 & 8.8 & $2.0^{*}$ & $2.2^{*}$ & $3 \cdot 7^{*}$ & $7 \cdot 0^{*}$ \\
\hline & & $(11.2)$ & $(12.0)$ & $(-19 \cdot 3)$ & $(4.8)$ & & & $(10.7)$ & $(13 \cdot 7)$ & (11.9) & (12.0) \\
\hline
\end{tabular}


Table 3. Observed year-on-year monthly value-added growth rate of China's manufacturing sectors (\%)

\begin{tabular}{|c|c|c|c|c|c|c|c|c|c|c|c|}
\hline Sectors & Abbr. & Nov 19 & Dec 19 & Feb 20 & Mar 20 & Apr 20 & May 20 & Jun 20 & Jul 20 & Aug 20 & Sep 20 \\
\hline 20. Instrument and meter & OME & 11.0 & $3 \cdot 4$ & $-27 \cdot 4$ & 2.0 & 11.1 & 8.4 & 6.6 & $9 \cdot 4$ & 3.8 & 3.0 \\
\hline 21. Other manufacturing & $\mathrm{OMF}$ & 1.3 & $-3 \cdot 9$ & -25.0 & -12.9 & -4.8 & $-5 \cdot 4$ & -7.1 & -0.4 & 0.4 & 4.0 \\
\hline $\begin{array}{l}\text { 22. Electricity and hot water } \\
\text { production and supply }\end{array}$ & ELE & 6.8 & 7.0 & -6.0 & -1.7 & -0.2 & 4.0 & 6.3 & 1.7 & $5 \cdot 9$ & 4.2 \\
\hline $\begin{array}{l}\text { 23. Gas and water produc- } \\
\text { tion and supply }\end{array}$ & GAS & 6.6 & 6.6 & -6.0 & -0.8 & 2.0 & 1.6 & 1.3 & 1.0 & 4.8 & 4.0 \\
\hline Average & & 5.2 & 4.8 & -18.4 & $-3 \cdot 0$ & 2.3 & 2.8 & 2.4 & 2.2 & 3.6 & 5.0 \\
\hline
\end{tabular}

Note: We only include manufacturing sectors. Based on authors' compilation from China's National Bureau of Statistics and concordance between IO sectors and industrial sectors in the industrial classification for national economic activities in Guobiao (GB)/T 4754-2011. We use the average year-on-year growth rate of all GB sectors that correspond with the IO sector as the growth rate of a specific IO sector. Please note that the data are for enterprises with annual revenue above 20 million RMB and we combine metal and non-metal mining (sector 4 and 5), and metal products and general and specialist machinery (sector 15 and 16) to be consistent with the sectors in the general equilibrium trade model.

* For WAP and EEQ, values in bold value are the actual shocks used in the modeling, and values in brackets are the raw data in the CARD database. Note that for several sectoral shocks (labeled as "-"), we cannot find a reasonable value and omit them in the modeling. 


\section{General Equilibrium Structure}

To quantify the implied labor productivity and trade shocks that fit the observed data, we formulate a benchmark mathematical representation of the Chinese economy. Our formulation relies on Mathematical Programming System for General Equilibrium (MPSGE) (Rutherford 1999) as a modeling environment embedded within the General Algebraic Modeling System (GAMS) (Brooke et al. 1988) software. MPSGE offers a convenient representation of a standard general equilibrium as a mixed complementary problem in the Mathiesen-Rutherford tradition. ${ }^{9}$

The general structure of a Mathiesen-Rutherford general equilibrium defines a set of complementary-slack conditions around markets indexed by $p$, transformation activities indexed by $q$, and households indexed by $h$. Let us define the variable $X_{q}$ as a quantity index on a constant-returns activity that transforms inputs into outputs. The associated unit value functions represent the technology and optimizing behavior. That is, the minimized unit-cost function, $c_{q}(\boldsymbol{p})$, where $p$ is the vector of prices, gives the marginal cost. The maximized unit-revenue function $r_{q}(\boldsymbol{p})$ gives us the marginal revenue. ${ }^{10}$ With initial quantity $x 0_{q}$, we can represent the optimized profit function as

$$
\Pi_{q}\left(\boldsymbol{p}, x 0_{q} X_{q}\right)=x 0_{q} X_{q}\left(r_{q}(\boldsymbol{p})-c_{q}(\boldsymbol{p})\right)=x 0_{q} X_{q} \pi_{q}(\boldsymbol{p}) .
$$

Activities intensify up to the point that they drive profits to zero in a competitive general equilibrium. The following represents the complementary-slack condition as indicated in the MPSGE software:

$$
c_{q}(\boldsymbol{p})-r_{q}(\boldsymbol{p}) \geq 0, \quad X_{q} \geq 0, \quad \text { and } \quad X_{q}\left(c_{q}(\boldsymbol{p})-r_{q}(\boldsymbol{p})\right)=0 ; \quad \forall q .
$$

Logically, the three conditions embedded in (1) indicate that unit profits are zero for any activity with positive output $\left(x 0_{q} X_{q}>0\right)$, but output is zero for an unprofitable activity. Also note that the constant-returns assumption on technologies allows us to eliminate the benchmark output level, $x 0_{q}$, from (1), which is a convenient default scaling such that the activity level, $X_{q}$, is an index. Of course, one might multiply through each condition in (1) by $x 0_{q}$ without changing the economics of the problem.

The next set of conditions are the market clearance conditions associated with the prices. Let $P_{p}$ be an element of the price vector, $p$. Any scarce commodity will

9 Rutherford (1999) presents the original Mathiesen (1985) algebraic formulation of a general equilibrium as a complementarity problem and its representation in MPSGE. While Mathiesen's original formulation and algorithm includes a sequence of linear complementarity problems, GAMS solves non-linear complementarity problems directly by calling advanced algorithms or solvers. In our case, we use the PATH solver (Ferris and Munson 2000).

${ }^{10}$ In the special case of a transformation activity with a single output, unit-revenue is simply the price of that output (e.g., $\left.p_{q}\right)$. 
have a strictly positive price, and supply will equal demand. The sources of supply include endowments and outputs from activities, and the sources of demand include final demand and inputs to activities. Let the endowment of commodity $p$ to household $h$ be $E_{p h}$. The Marshallian demand functions $D_{p h}\left(\boldsymbol{p}, W_{h}\right)$, where $W_{h}$ gives the total income for household $h$, indicate final demand for commodity $p$. We recover demands and supplies from transformation activities by applying the envelope theorem (Hotelling's lemma). The complementary-slack condition generated through the MPSGE software is

$$
\begin{gathered}
\sum_{h}\left(E_{p h}-D_{p h}\left(\boldsymbol{p}, W_{h}\right)\right)+\sum_{q} x 0_{q} X_{q} \frac{\partial \pi_{q}(\boldsymbol{p})}{\partial P_{p}} \geq 0, \quad P_{p} \geq 0, \quad \text { and } \\
P_{p}\left[\sum_{h}\left(E_{p h}-D_{p h}\left(\boldsymbol{p}, W_{h}\right)\right)+\sum_{q} x 0_{q} X_{q} \frac{\partial \pi_{q}(\boldsymbol{p})}{\partial P_{p}}\right]=0 ; \quad \forall p .
\end{gathered}
$$

The default chooses units such that all $P_{p}$ are one at the benchmark equilibrium. This is a convenient scaling such that the prices are indexes.

The next set of equilibrium conditions determine the nominal income levels for each agent or household $h$. Expenditures cannot exceed the value of endowments plus net tax revenues. Let $T_{h}$ indicate the total net tax revenues allocated to agent $h$ such that the complementarity condition is

$$
\begin{array}{r}
\sum_{p}\left(P_{p} E_{j h}-P_{p} D_{j h}\left(\boldsymbol{p}, W_{h}\right)\right)+T_{h} \geq 0, \quad W_{h} \geq 0, \quad \text { and } \\
W_{h}\left[\sum_{p}\left(P_{p} E_{j h}-P_{p} D_{j h}\left(\boldsymbol{p}, W_{h}\right)\right)+T_{h}\right]=0 ; \quad \forall h .
\end{array}
$$

While the technical formulation depends on a multitude of complementary-slack conditions, some conditions will logically simplify to equality constraints. For example, in condition (3) we will always have $W_{h}=\sum_{p} P_{p} E_{j h}+T_{h}>0$ for any nontrivial household. Conditions (1), (2), and (3) represent the core set of equilibrium conditions. The conditions only indicate relative prices, thus we establish a price normalization that indicates the units associated with nominal measures. The numeric solution includes activity indexes, relative prices, and nominal incomes.

Adding auxiliary variables and related conditions or constraints introduces considerable flexibility into the competitive general equilibrium. Within MPSGE these affect the core equilibrium in the form of endogenous taxes and endowment adjustments. For example, tax rates might be adjusted to meet a given revenue target, or labor supply might be rationed to meet a given minimum wage. In the context of our analysis, we introduce a set of COVID-19 productivity and trade shocks that adjust endogenously to move the benchmark equilibrium to the observed 2020 data. The goal is to compute, report, and interpret these shocks.

Table 4 outlines the full set of variables in our model of the Chinese economy. We classify these variables into the MPSGE categories with descriptions and dimen- 
sions. To facilitate the description, it is useful to define the sets embodied in the data. Let the indexes $i \in I$ or $j \in I$ indicate an industry or its associated commodity. Let $r \in R$ indicate a Chinese province or region, and let $s \in S$ indicate a foreign trade partner. ${ }^{11}$ The set $G$ is the union of $I$ and $R(g \in G=I \cup R)$. This is useful because we aggregate inputs of good $j$ (across domestic and imports) for industry $i$ and for final demand in region $r$. Thus, the input demand activity, $I D_{i g r}$, provides an Armington aggregation over domestic and foreign varieties to industries and the regional household. Note in Table 4 that the acronym "CET" indicates a constant-elasticity-of-transformation activity where a single input transforms into multiple outputs. We also use the acronym "CES" to indicate standard constant-elasticity-of-substitution technologies.

We calibrate the model to the China MRIO table developed by Mi et al. (2018). We structure the model around the data with CES and CET technologies. Each transformation activity in Table 4 will be associated with an equilibrium condition analogous to (1). Calibration involves specifying the CES and CET unit value functions, $c_{q}(\boldsymbol{p})$ and $r_{q}(\boldsymbol{p})$, and endowments such that the social accounts satisfy the equilibrium conditions. Each price and income-level variable declared in Table 4 will have an associated equilibrium condition analogous to (2) and (3). In our application, there are deviations from the generalized structure, which we now elaborate. ${ }^{12}$

First, we outline our non-standard treatment of utility and final demand. We abstract from multiple household types within a region and alternative final demand categories. Thus, for each region, there is a single representative-agent expenditure function covering private consumption, investment, and government spending. It is convenient to replace the Marshallian demand functions in (3) by explicitly modeling the representative agent's expenditures as a linearly-homogeneous "utility" activity $U_{r}$. Let $e_{r}(\boldsymbol{p})$ be a Cobb-Douglas unit expenditure function calibrated to each region's final demand, and let $P U_{r}$ be the true-cost-of-living index (or price of utility). The equilibrium conditions when we model utility as an activity (while noting that there will be no slack agents) are

$$
e_{r}(\boldsymbol{p})-P U_{r}=0 \text { and } U_{r}>0 ; \quad \forall r \in R .
$$

Introducing the price of utility has associated market clearance conditions:

$$
U_{r}-\frac{R A_{r}}{P U_{r}}=0 \text { and } P U_{r}>0 ; \quad \forall r \in R .
$$

For any other commodity's market-clearance condition, we replace the Marshal-

${ }^{11}$ Currently, we distinguish between Chinese trade with the United States and the restof-world region $(S=\{U S A$, row $\})$.

${ }^{12}$ In the interest of brevity, we do not enumerate all equilibrium conditions that correspond to the variables presented in Table 4 because they largely mimic conditions (1), (2), and (3); however, the authors will make the model code available to interested readers. 
Table 4. Scope of China regional model

\begin{tabular}{|c|c|c|}
\hline Variable & Description & Dimensions \\
\hline \multicolumn{3}{|c|}{ Transformation Activities $\left(X_{q}\right)$} \\
\hline$Y_{i r}$ & Production & $I \times R$ \\
\hline$C E T_{\text {ir }}$ & CET supply: domestic versus foreign & $I \times R$ \\
\hline$I D_{i g r}$ & Armington aggregation: domestic and foreign & $I \times I \times R$ \\
\hline$A_{j r}$ & Armington aggregation: domestic-provincial goods & $I \times R$ \\
\hline$M_{i}$ & Armington aggregation: foreign & $I$ \\
\hline$M B_{\text {is }}$ & Bilateral import & $I \times S$ \\
\hline$K X_{r}$ & CET activity for sector-specific capital & $R$ \\
\hline$U_{r}$ & Utility (final demand) & $R$ \\
\hline \multicolumn{3}{|c|}{ Markets $\left(P_{p}\right)$} \\
\hline$P Y_{i r}$ & Output price (input to domestic-foreign CET) & $I \times R$ \\
\hline$P R_{i r}$ & Regional output price for domestic use & $I \times R$ \\
\hline$P X_{i}$ & Export price & $I$ \\
\hline$P I_{\text {igr }}$ & Top-level Armington price of $i$ input to $g$ & $I \times I \times R$ \\
\hline$P A_{\text {ir }}$ & Armington composite over provincials & $I \times R$ \\
\hline$P M_{i}$ & Armington composite over imports & $I$ \\
\hline$P M B_{\text {is }}$ & Bilateral import price & $I \times S$ \\
\hline$R K_{i r}$ & Sector-specific capital price & $I \times R$ \\
\hline$R K X_{r}$ & Price of generic capital endowment & $R$ \\
\hline$P L_{r}$ & Wage rate & $R$ \\
\hline$P U_{r}$ & True-cost-of-living index & $R$ \\
\hline PFX & Price of foreign exchange (numeraire) & 1 \\
\hline \multicolumn{3}{|c|}{ Households $\left(W_{h}\right)$} \\
\hline$R A_{r}$ & Provincial Representative Agent Income & $R$ \\
\hline ROW & Rest of world (export-demand import-supply agent) & 1 \\
\hline \multicolumn{3}{|l|}{ Auxiliary } \\
\hline$X D_{i}$ & Export demand (constant elasticity) & $I$ \\
\hline$\rho_{r}$ & Provincial-labor rationing index & $R$ \\
\hline$\phi_{i}$ & Sectoral targeting parameter (phantom subsidy) & $I$ \\
\hline$\tau$ & Export-demand shock index & 1 \\
\hline$v$ & Balance-of-payments (capital-account) rationing & 1 \\
\hline
\end{tabular}


lian demands in (2) with compensated or conditional demands, which are a function of the level of utility. This formulation is convenient because $U_{r}$ is a theoretically consistent index of utility evaluated at initial prices. Equivalent variation is $u 0_{r}\left(U_{r}-1\right)$, where $u 0_{r}$ is benchmark nominal expenditures. The computed equilibrium is equivalent to specifying the Marshallian demand functions as indicated in (2) and (3), but having a direct welfare report motivates the treatment of utility as a transformation activity.

We proceed with an explanation of the formulation of international and interregional trade. On the import side, the import activities, $M B_{i s}$, transform the foreign-exchange good trading at price PFX into a bilateral import good, trading at price $P M B_{i s}$ for good $i$ from foreign region $s$. These bilateral import goods are, in turn, transformed into a CES Armington composite of foreign goods, with the composite trading at a price $P M_{i}$ for good $i$ through activity $M_{i}$. Inter-regionally, the composite good in region $r$ trading at a price $P A_{i r}$ is a CES aggregate of imported domestic goods from other provinces. Finally, the activity $I D_{i g r}$ aggregates home-province goods with the foreign and domestic composites to produce the input of good $i$ for sector $g$ in region $r, P I_{i g r}$.

Moving to the export side, we explain our export-demand formulation. The activity $C E T_{i r}$ transforms productive output into either an export good trading at a price $P X_{i}$ or a region-specific domestic good trading at a price $P R_{i r}$. The export good is sold to generate foreign-exchange at price PFX. The market-clearance condition on PFX is the balance-of-payments constraint, as export activities generate foreign exchange (and the capital-account surplus) and foreign exchange is used to buy imports. We add an agent, with income $R O W$, to facilitate the formulation. The added auxiliary variable $X D_{i}$ rations the rest-of-world demand for China's exports to be consistent with a large-open-economy structure. Let $x d 0_{i}$ be the benchmark level of exports of good $i$, and let the export-demand function be $f\left(P X_{i}, P F X\right)$, where the arguments are the price of exports and the price of foreign exchange. We add the complementary-slack relationship for the index $X D$ to the model:

$$
\begin{array}{r}
x d 0_{i} X D_{i}-\tau f\left(P X_{i}, P F X\right) \geq 0, X D_{i} \geq 0, \quad \text { and } \\
X D_{i}\left(x d 0_{i} X D_{i}-\tau f\left(P X_{i}, P F X\right)\right)=0 .
\end{array}
$$

The export-demand function is the sum of the conditional demands across trade partners $s$ indicated by the nested CES Armington structure in the GTAPINGAMS model. ${ }^{13}$ With a finite export demand elasticity, we have a large-open-economy

13 The GTAPINGAMS model is a multiregion international trade model with explicitly modeled foreign regions (Lanz and Rutherford 2016). Our formulation models all non-Chinese regions parametrically through export demand functions, but because model development considered the regional impacts of the U.S.-China trade war, the export demand functions are rather elaborate and account for each foreign region's Chinese import share, transport margins, and discriminatory tariffs. The authors can provide details on the precise 
structure where there are adverse terms-of-trade effects of expanded trade. Export demand falls as PFX rises, but export demand contracts as PX rises.

We introduce the endogenous variable $\tau$ in equation (6), which is an exportdemand shifter fixed at one if there is no international-trade targeting in the scenario. If we do want to account for changes in China's international trade opportunities induced by the COVID-19 shocks, we adjust $\tau$ to hit a given export target, and we adjust $v$ to hit a given import target. First, we consider export targeting. Let $\overline{E X}$ be the exogenous target for aggregate exports. The following complementary slack condition is associated with $\tau$ :

$$
\begin{array}{r}
\frac{\sum_{i} \tau P X_{i} f\left(P X_{i}, P F X\right)}{P F X}-\overline{E X} \geq 0, \quad \tau \geq 0, \quad \text { and } \\
\tau\left[\frac{\sum_{i} \tau P X_{i} f\left(P X_{i}, P F X\right)}{P F X}-\overline{E X}\right]=0 .
\end{array}
$$

Similarly, we have a condition for import targeting:

$$
\begin{array}{r}
\frac{\sum_{i} m t 0_{i} P M_{i} M_{i}}{P F X}-\overline{I M} \geq 0, \quad v \geq 0, \quad \text { and } \\
v\left[\frac{\sum_{i} m t 0_{i} P M_{i} M_{i}}{P F X}-\overline{I M}\right]=0 ;
\end{array}
$$

where $m t 0_{i}$ is the benchmark level of good $i$ imports and $\overline{I M}$ is the import target. The variable $v$ does not directly impact the productivity of imports, but rather rations the foreign exchange good as it is transferred to Chinese agents through the capital account. In general targeting, both imports and exports will indicate an adjustment in the capital account balance. Equation (7) determines the foreign exchange generated through exports. Rationing the transfers of PFX through the capital account yields the appropriate level of aggregate imports, which the regional agent's budget best illustrates. Let the labor and capital endowments be $\bar{L}_{r}$ and $\bar{K}_{r}$. Denote the benchmark net trade surplus $\overline{C A}_{r}$ as observed in the accounts, which if positive indicates a transfer of foreign exchange to foreign agents through a capital account deficit. In the benchmark calibration, a negative endowment of PFX represents this transfer. Then, the following gives the nominal income for the representative agent:

$$
\begin{aligned}
R A_{r}= & \operatorname{PL}_{r}\left(\rho_{r} \bar{L}_{r}\right) \\
& +\operatorname{RKX}_{r}\left(\bar{K}_{r}\right) \\
& -\operatorname{PFX}\left(v \overline{C A}_{r}\right) \\
& +T_{r} .
\end{aligned}
$$

Under trade targeting, $v$ adjusts according to (8) such that the amount of foreign exchange available sufficiently meets the import target. If we do not have trade

formulation of $f\left(P X_{i}, P F X\right)$. 
targeting, $v=1$ and we ignore (8). That is, without trade targeting we have the standard assumption that there is no change in the net trade surplus.

In the regional budget (9) we include $\rho_{r}$ as the instrument for adjusting the productivity of the regional labor force. Notice that we can interpret the adjustments in $\left(\rho_{r} \bar{L}_{r}\right)$ as any combination of adjustments in the quantity of labor or productivity per worker. Distinguishing across these margins requires additional information. As with the rest of the model, a complementarity condition determines $\rho_{r}$. Let $\overline{V A}_{r}$ give the proportional value-added target relative to the benchmark. The equilibrium condition associated with $\rho_{r}$ is:

$$
\begin{array}{r}
\overline{V A}_{r}\left(\bar{L}_{r}+\bar{K}_{r}\right)-\left(\rho_{r} P L_{r} \bar{L}_{r}+R K X_{r} \bar{K}_{r}\right) / P F X \geq 0, \quad \rho_{r} \geq 0, \quad \text { and } \\
\rho_{r}\left[\overline{V A}_{r}\left(\bar{L}_{r}+\bar{K}_{r}\right)-\left(\rho_{r} P L_{r} \rho_{r} \bar{L}_{r}+R K X_{r} \bar{K}_{r}\right) / P F X\right]=0 .
\end{array}
$$

The value-added target is interpreted as a real target and thus the first term in (10) is devoid of prices. Value-added in the model, however, is inherently a nominal measure once the component prices move away from their benchmark normalization. Dividing the measured value-added by PFX makes it explicit that the real constraint is in numeraire units. ${ }^{14}$

The final model extension indicates our approach to sectoral targeting. We add the instrument $\phi_{i}$ and associated complimentarity condition to the model such that we are able to target the output of a given sector across the Chinese economy. Consider that, in the equilibrium, a pure productivity shock for a given activity is equivalent to one plus an ad valorem subsidy or tax that collects no revenue. Researchers sometimes refer to this in the literature as a phantom tax or subsidy (Dixon and Rimmer 2002). To illustrate, we first present the complementarity condition for production inclusive of the instrument. Consistent with (1), there is a complementarity condition for production in each region and sector:

$$
c_{i r}(\boldsymbol{p})-\left(1+\phi_{i}\right) P Y_{i r} \geq 0, \quad Y_{i r} \geq 0, \quad \text { and } \quad Y_{i r}\left(c_{i r}(\boldsymbol{p})-\left(1+\phi_{i}\right) P Y_{i r}\right)=0 .
$$

The instrument $\phi_{i}$ enters as a uniform endogenous subsidy on the unit revenue in sector $i$ across all regions $r$. The equivalent total-productivity-shock associated with a non-zero $\phi_{i}$ is $\left(1+\phi_{i}\right)=\operatorname{TFP}_{i}$. For example, if $\phi_{i}=0.1$, then productivity of inputs increase by $10 \%$, which is equivalent to a new unit-cost function $\tilde{c}_{i r}=$ $c_{i r} / 1.1 .{ }^{15}$ Denoting the sectoral target $\bar{Y}_{i}$, we include the following condition to

14 While we can fix the value of the numeraire PFX at one numerically, excluding it from (10) is problematic because it indicates an equilibrium condition that is not homogeneous of degree zero in prices. The general equilibrium solution should not be numeraire dependent.

${ }^{15}$ An inconvenient feature of the MPSGE software, in our context, is that endogneous taxes automatically generate revenue for some agent and some agent must fund endogenous subsidies. To accommodate $\left(1+\phi_{i}\right)$ as a productivity shock, we have to add another auxiliary variable that wipes out the tax revenue or funds the subsidy payment for the assigned agent. This is a software correction, however, and not an element of the economic 
determine the $\phi_{i}$ :

$$
\begin{array}{r}
\frac{\sum_{r} y 0_{i r} P Y_{i r} Y_{i r}}{P F X}-\bar{Y}_{i} \geq 0, \quad \phi_{i}-(-0.99) \geq 0, \quad \text { and } \\
\left(\phi_{i}-(-0.99)\right)\left(\frac{\sum_{r} y 0_{i r} P Y_{i r} Y_{i r}}{P F X}-\bar{Y}_{i}\right)=0 .
\end{array}
$$

In the first term, unit consistency requires a nominal summation across regions. Again, we divide by PFX to maintain homogeneity in prices, and to indicate that the real constraint is in numeraire units. Notice that we bind $\phi_{i}$ to be greater than $(-0.99)$, and ad valorem subsidy no lower than $-99 \%$, so that unit revenue does not approach zero in computation. ${ }^{16}$

This section elaborates on the key features and model extensions as implemented in our analysis. The computer code is available from the authors upon request. In the next section, we present the results of our analysis.

\section{Results}

\subsection{Regional labor productivity shocks}

Tables A.1 and A.2 in the Appendix provide two full sets of COVID-19 provinceby-month labor-productivity-shock estimates for 30 provinces from November 2019 to September 2020 including and not including trade shocks as modeling targets, respectively. In February 2020, as a year-on-year comparison, when compared with February 2019 levels and when trade series are included in the modeling, we find an average $39.5 \%$ decrease in labor productivity (equivalent to around 305 million jobs) and an average $25.9 \%$ decrease in welfare across provinces. ${ }^{17}$ Both China's labor productivity and welfare have quickly returned to the recent high-growth trends for China in the latter half of 2020. As of September 2020, average labor productivity increased by $12.2 \%$ (equivalent to around 94 million jobs) and average welfare increased by $8.2 \%$ compared to September 2019 levels.

For illustration purposes, Figure 2 presents the monthly year-on-year percentage changes in labor productivity in Beijing, Hubei, Heilongjiang, Zhejiang, and Xinjiang. Panel A presents the estimates without trade shocks as additional modeling targets, and panel B presents the estimates with trade shocks as targets.

In panel A, compared with levels in February and March 2019, Hubei's labor productivity reduced by $74.1 \%$ and $72.9 \%$ in February and March 2020, respectively. However, Hubei's labor productivity has returned since May 2020 and increased to $19.4 \%$ as of September 2020 compared to 2019 levels. This pattern is consistent with the draconian lockdown measures Hubei adopted. Beijing and Zhejiang's labor productivity reduced by $43.9 \%$ and $46.0 \%$, respectively, in Febru-

equilibrium, so we do not elaborate. The authors can provide additional information.

${ }^{16}$ Solution values of $\phi_{i}$ are never at their lower bound.

17 We base this decrease on the baseline employment of 774 million in 2019. 
ary 2020 compared to February 2019 levels, while Xinjiang's labor productivity reduced by only $14.7 \%$ in February 2020 compared to February 2019 levels. These patterns are in line with COVID-19's spatial progression patterns. In addition, labor productivity in all five examined provinces gradually returned to the recent high-growth trends for China in the latter half of 2020 and reached an average year-on-year growth rate of around $32.0 \%$ as of September 2020. While Beijing was initially one of the fastest-recovering provinces (cities), the COVID-19 outbreak in Beijing in August and the associated strict lockdown measures thereafter have since slowed Beijing's recovery. 


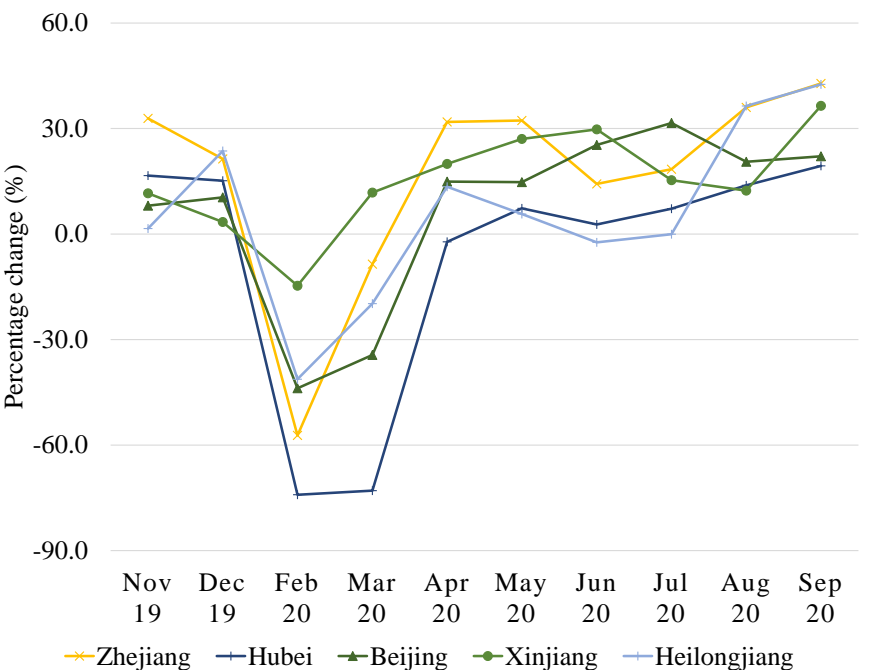

(a) Without trade shocks
60

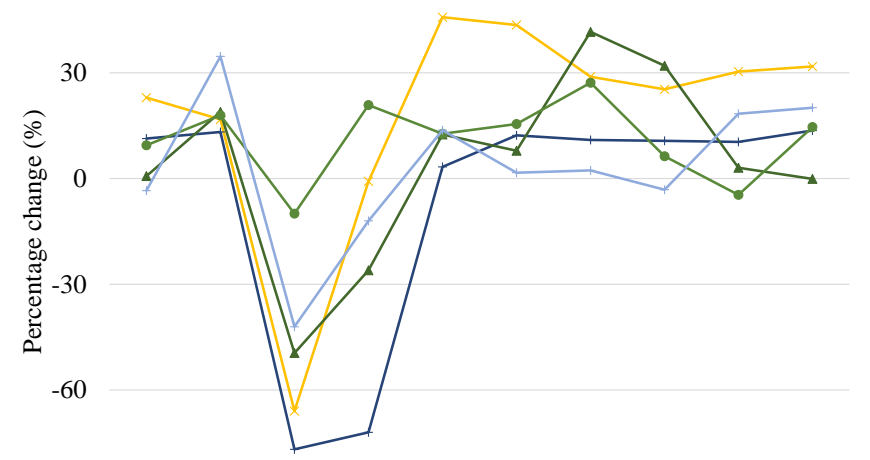

$-90$

Nov Dec Feb Mar Apr May Jun Jul Aug Sep $\begin{array}{llllllllll}19 & 19 & 20 & 20 & 20 & 20 & 20 & 20 & 20 & 20\end{array}$

$*$ Zhejiang - Hubei $₫$ Beijing $\rightarrow$ Xinjiang - Heilongjiang

(b) With trade shocks

Figure 2. Labor productivity shock estimates in five typical provinces with and without trade shocks (\%) 
Compared with panel A, panel B in Figure 2 accounts for trade shocks and thus shows different recovery patterns. From April to June, labor productivity grew faster when not including trade shocks as additional targets in the modeling. For example, Zhejiang's labor productivity grew by $31.9 \%, 32.3 \%$, and $14.2 \%$ in April, May, and June, respectively, compared with their 2019 levels when we do not include trade shocks as additional targets, which is lower than its labor productivity year-on-year growth rates of $45.8 \%, 43.6 \%$, and $28.9 \%$ in April, May, and June, respectively, when we include trade shocks as additional targets. The fact that China's net export demand declined from April to June can explain this pattern. Therefore, to achieve the same output when net export demand remains unchanged, we need to compensate export demand decline with higher labor productivity growth. These patterns reversed in August and September, partially because China's exports began accelerating in August (this is especially true for provinces in eastern China). As a result, labor productivity growth without trade shocks as targets was smaller than the labor productivity growth with trade shocks in August and September 2020.

To examine the spatial patterns of labor productivity shocks, we present the monthly population-weighed average labor productivity shocks in six regions in Figure $3 .{ }^{18}$ February 2020 shows a clear pattern-provinces in south-central and eastern China were most affected while northwestern provinces were least affected. We also find significant heterogeneity in recovery patterns across regions. Specifically, provinces in eastern China grew fastest from a labor productivity shock of $-45.1 \%$ in February to $39.2 \%$ in September 2020. The labor productivity recovery in northwestern China is most stable and increased from a negative shock of $-23.3 \%$ in February to $23.3 \%$ in September 2020. The south-central region, where Hubei is located, grew from a negative shock of $-43.8 \%$ in February to $24.0 \%$ in September. Similar to provincial patterns, regional recovery patterns from April to June differ depending on whether we account for national trade shocks. Most regions' labor productivity grew faster in April, May, and June, and reached a smaller growth rate in August and September when we do not include trade shocks. The net-export growth since August 2020 can help explain this change.

${ }^{18}$ We weight the provincial labor productivity shocks with 2019 provincial population. 
60

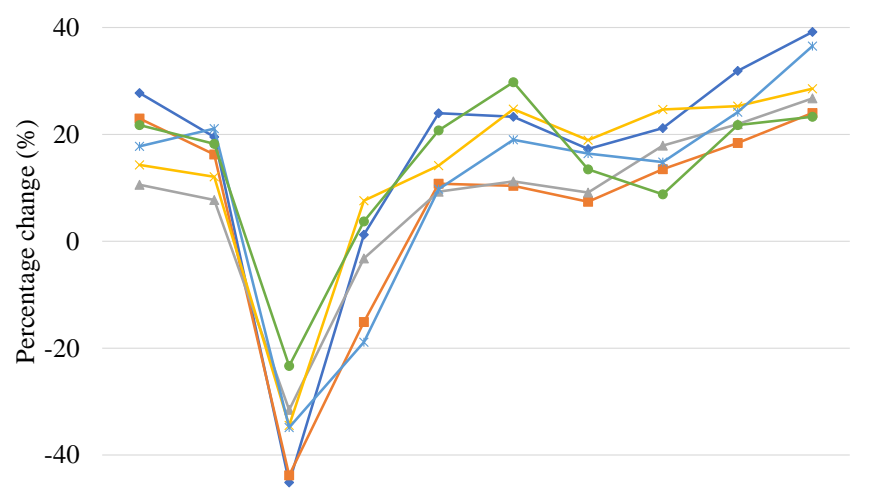

$-60$

$$
\begin{array}{cccccccccc}
\text { Nov } & \text { Dec } & \text { Feb } & \text { Mar } & \text { Apr } & \text { May } & \text { Jun } & \text { Jul } & \text { Aug } & \text { Sep } \\
19 & 19 & 20 & 20 & 20 & 20 & 20 & 20 & 20 & 20 \\
& \rightarrow \text {-East } & & - \text {-South-central }- \text {-North } \\
& \text { *-Southwest } & & \text {-Northeast } \rightarrow \text {-Northwest }
\end{array}
$$

(a) Without trade shocks
60

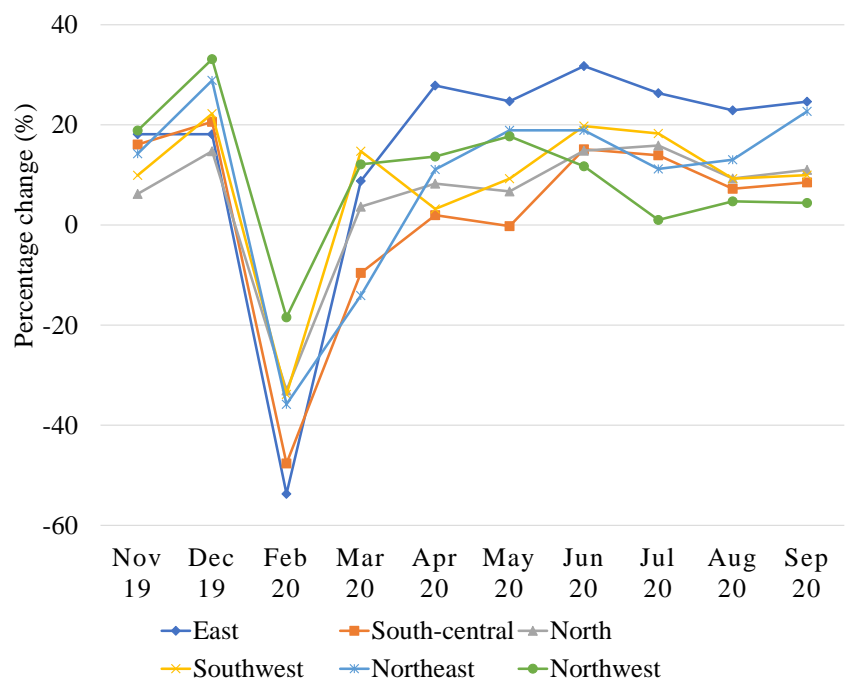

(b) With trade shocks

Figure 3. Labor productivity shock estimates in six regions with and without trade shocks (\%)

Note: The average labor productivity shock estimates in a region is the average labor productivity shock estimates weighted by 2019 population across provinces. 
There are several points worthy of attention when interpreting the labor productivity estimates. First, the labor productivity estimates are combinations of COVID-19 pandemic's productivity and employment effects, which suggests that the labor productivity estimates include changes in employment status, working hours, and output per working hour. Therefore, the estimated 293 million job loss in February 2020 should be interpreted as a 293 million full-time-equivalent job loss that can be any combination of changes in working hours, employment status, or output per working hour. ${ }^{19}$ Second, the value-added and trade targets used in the CGE modeling are the results of both the COVID-19 pandemic and various government policies, such as deferred tax payments for small and medium-sized firms, lower lending rates, and subsidies for infected medical workers' compensations. Given it is likely that policy changes and the potential adoption of smart technologies could change labor productivity, the labor productivity estimates derived from the model capture the net impacts of the pandemic and the various government policies. If government policies such as welfare programs increase demand, then we underestimate the negative labor productivity estimates in the first few months of the COVID-19 pandemic.

Given that for each province CNBS only reports year-end employment data and does not provide monthly data, we use the estimated unemployment rate from a survey conducted by China Center for Economic Research to compare our estimated employment effect and the actual employment loss in February 2020. ${ }^{20}$ This survey tracked the employment status of 4,539 workers and reported an average employment rate of $64.92 \%$ at the end of February 2020, which suggests an unemployment rate of $36.08 \%$. This impact is similar in magnitude to our estimated national average labor productivity shocks of $-37.9 \%$ without trade shocks (Table A1 in the Appendix) and $-39.5 \%$ with trade shocks (Table A2 in the Appendix).

\subsection{Labor productivity shock estimates and COVID-19 cases}

Figure 4 plots the relationship between labor productivity shock estimates and the ratio of cumulative confirmed COVID-19 cases in China's 2019 population in February, March, and April 2020 across provinces. There is a clear negative relationship between ratio of confirmed cases and labor productivity shock estimates in February; however, the negative relation disappears in March and April. This shows that areas hit harder by COVID-19 suffered greater labor productivity loss initially; however, it is only evident in February, which is in line with the fact that the pandemic was largely contained and the economic activities resumed in April 2020.

${ }^{19}$ COVID-19's employment effects are heterogeneous across demographic subgroups, regions, and industries (Barwick et al. 2020).

${ }^{20}$ Details of the survey are available at http://nsd.pku.edu.cn/docs/20210901150940381641.pdf. 


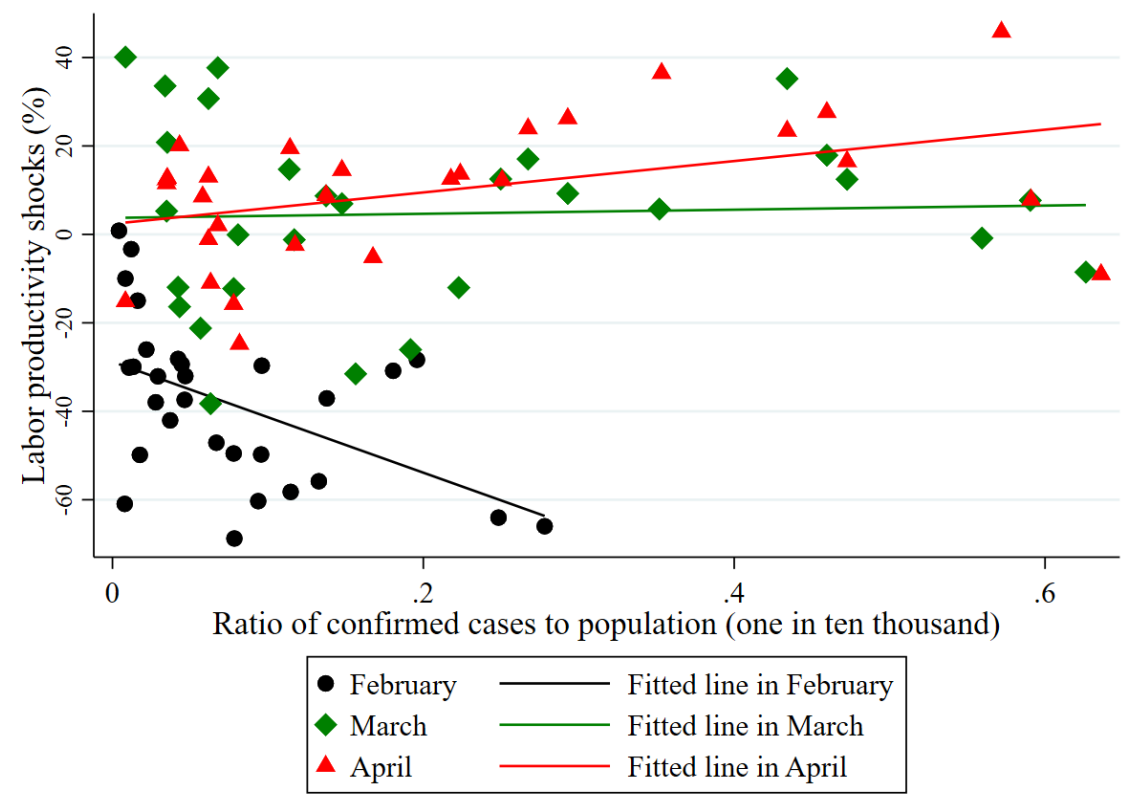

Figure 4. Scatter plot of labor productivity shock estimates and ratio of cumulative confirmed cases to population, 2020

Note: We base the ratio of confirmed cases to population on 2019 population. Data on cumulative confirmed cases come from China's Center for Disease Control and Prevention (China CDC). Labor productivity shock estimates are estimated with trade shocks as additional targets. For clear illustration, we exclude Hubei from the figure due to its ratio of confirmed cases to population. 


\subsection{Regional welfare impacts}

Tables A.3 and A.4 in the Appendix provide two full sets of COVID- 19 provinceby-month welfare impacts for 30 provinces from November 2019 to September 2020 estimated from models with and without trade shocks as additional targets, respectively. We base our welfare calculations on equivalent variation and measure households' money-metric income loss (gain). Figure 5 presents the monthly percentage changes in welfare in Beijing, Hubei, Heilongjiang, Zhejiang, and Xinjiang. Panel A shows welfare changes without trade shocks as targets, and panel B shows the estimated welfare impacts when we incorporate national shocks in the modeling. Compared with the monthly levels in 2019, Hubei's welfare reduced by $54.1 \%$ and $54.3 \%$ in February and March 2020, respectively, and returned to a growth rate of $3.9 \%$ in May 2020. In addition, although Xinjiang's value-added only fell by $0.7 \%$ in February 2020 (as shown in Table 2), its welfare fell by $8.8 \%$ that same month, which indicates that output impacts might disguise labor productivity and welfare impacts. In addition, welfare in all five provinces returned to the recent high-growth trends for China in the latter half of 2020. By September 2020, relative to September 2019, welfare reached a growth rate of around $17.0 \%$. The welfare shocks over time are consistent with the temporal labor productivity shocks in that Zhejiang rebounded fastest, followed by Beijing. Beijing's welfare recovery has slowed since August due to a COVID-19 outbreak. In addition, the magnitudes of the percentage changes in welfare are smaller than the percentage changes in labor productivity.

The reason that labor productivity and welfare estimates are different is because we define welfare in changes in equivalent variation, which makes the link between a region's labor productivity and welfare complex. A region's change in welfare will reflect the full set of price changes across the equilibrium as they enter the expenditure function (the price of consumer goods rises relative to income).

Another point worthy of mentioning is that the welfare estimates calculated from the general equilibrium model are the net impacts induced by both the pandemic and various demand and supply policies that could potentially affect production. If government subsidies and adoption of technologies affected production, then we could have overestimated the welfare estimates in non-COVID-19 periods. 
40

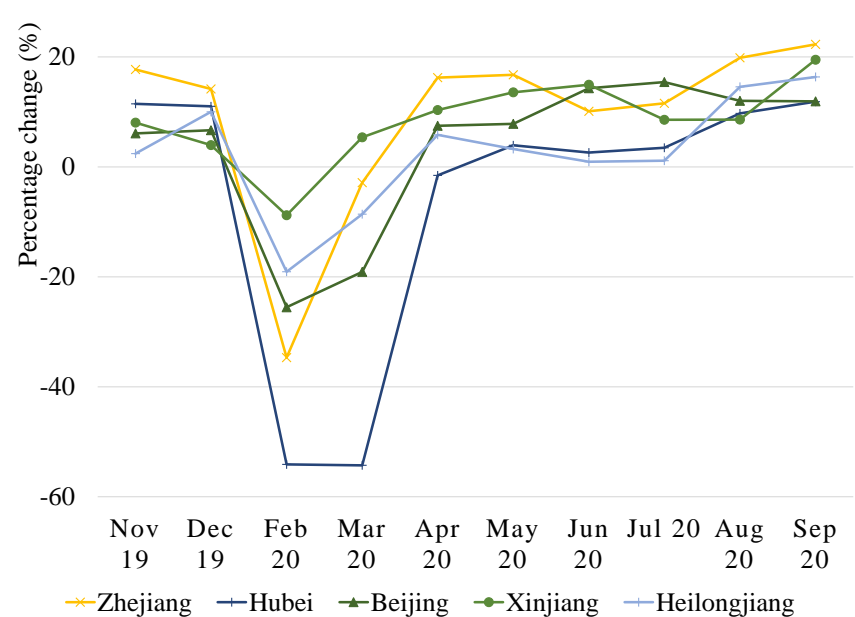

40

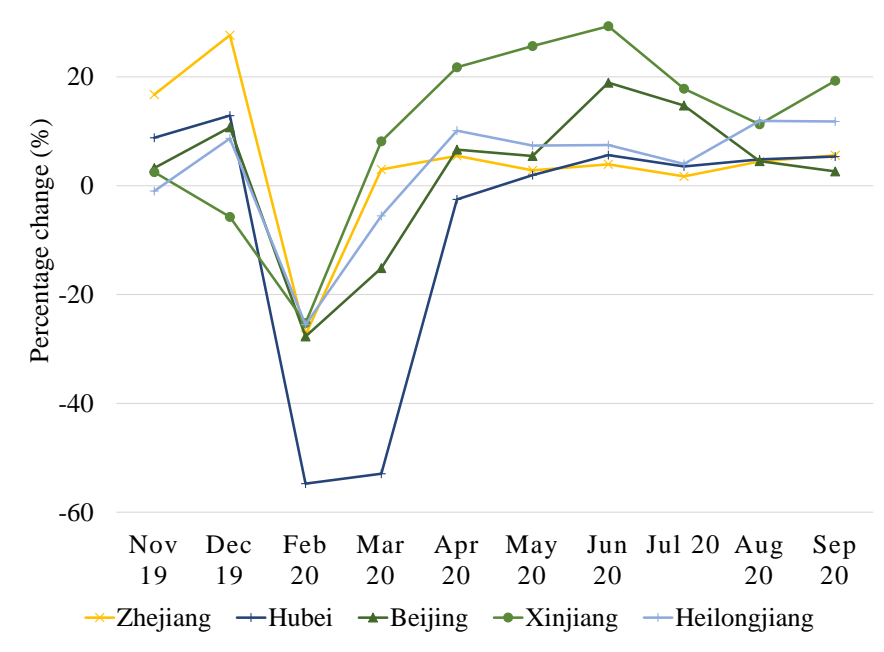

(b) With trade shocks

(a) Without trade shocks

Figure 5. Welfare changes in five typical provinces with and without trade shocks (\%) 
Figure 6 presents the year-on-year monthly percentage changes in welfare in six regions not including and including trade shocks as additional targets, respectively. Figure 6 shows that patterns are consistent with our welfare estimateseastern China recovered fastest. Similar to provincial patterns, regional growth patterns from April to June differ depending on whether we account for national trade shocks. Most provinces' welfare grew faster from April to June, when not accounting for trade shocks, and returned to lower levels starting in August, also when not accounting for trade shocks.

It is important to explain why welfare estimates are different with and without trade shocks incorporated in the model. With a positive trade shock, we need a more adverse productivity shock to meet the income target. With the trade shock, however, we get both terms-of-trade changes along with changes in the implied balance-of-payments transfer. Consider a positive export shock with little change in imports. In this case, there is an increase in the current account surplus, which indicates that China is transferring current income to the rest of the world through its increased acquisition of foreign assets (lending). This will generally make the welfare results, which are based on changes in current expenditures, sensitive to the inclusion of trade shocks. In the case without trade shocks we adopt the standard comparative-static assumption that the current account is fixed so there is no change in the implied balance-of-payments transfer.

\subsection{Spatial dynamics of labor productivity shocks}

The three maps in Figure 7 illustrate the spatial distribution of estimated provincial labor productivity shocks in February, June, and September 2020 without using national trade shocks as additional targets, which show spatial heterogeneity. While the initial negative labor productivity shocks concentrated in Hubei, eastern China, and parts of northeast and southwest China, the negative labor productivity shocks mostly disappeared in June. The severity of labor productivity shocks relate to provinces' proximity to Hubei and the stringency of control measures. Eastern China recovered the fastest while south-central provinces recovered

slowly. In September, labor productivity shocks in several provinces in northwestern China, such as Qinghai, grew slower than other provinces. The patterns are consistent with the COVID-19 pandemic hitting the northern and northwestern regions in July. 
40

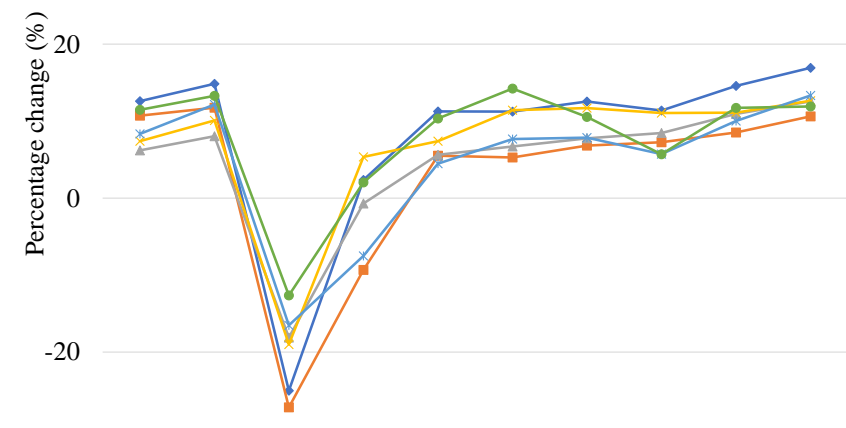

$-40$

$$
\begin{array}{cccccccccc}
\text { Nov } & \text { Dec } & \text { Feb } & \text { Mar } & \text { Apr } & \text { May } & \text { Jun } & \text { Jul } & \text { Aug } & \text { Sep } \\
19 & 19 & 20 & 20 & 20 & 20 & 20 & 20 & 20 & 20 \\
& \rightarrow \text {-East } & \multicolumn{1}{l}{- \text {-South-central }- \text {-North }} \\
& \text { - Southwest } & &
\end{array}
$$

(a) Without trade shocks
40

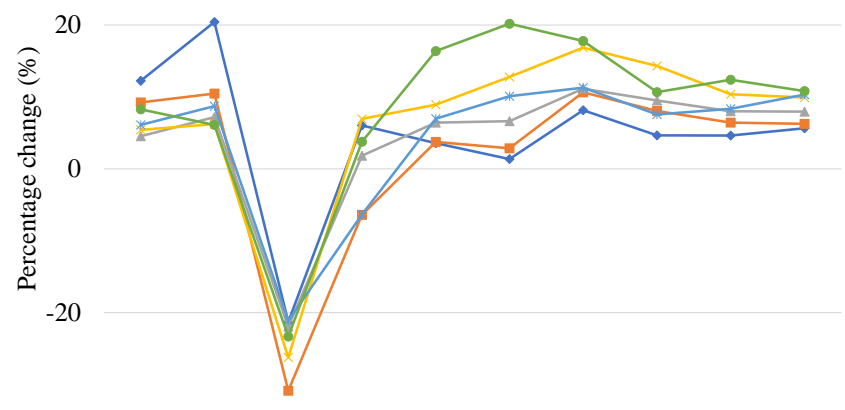

$-40$

$$
\begin{aligned}
& \begin{array}{cccccccccc}
\text { Nov } & \text { Dec } & \text { Feb } & \text { Mar } & \text { Apr } & \text { May } & \text { Jun } & \text { Jul } & \text { Aug } & \text { Sep } \\
19 & 19 & 20 & 20 & 20 & 20 & 20 & 20 & 20 & 20
\end{array} \\
& \rightarrow \text { East } \quad \rightarrow \text {-South-central }- \text {-North }
\end{aligned}
$$

(b) With trade shocks

Figure 6. Welfare changes in six regions with and without trade shocks (\%)

Note: The average labor productivity shock in a region is the average labor productivity shock weighted by 2019 population across provinces. 


\section{Conclusion and Discussion}

This paper first introduces a database that documents various monthly sectoral and regional economic outcomes in China, which we can use to analyze COVID19's impacts on China's economy. We use a general equilibrium model calibrated to a 30 provinces by 30 sectors MRIO table to quantify COVID-19's impacts on provincial labor productivity and welfare. As a year-on-year comparison, relative to February 2019 levels, when the trade series are included in the modeling, we find an average 39.5\% decrease in labor productivity (equivalent to around 305 million jobs) and an average $25.9 \%$ decrease in welfare. Labor productivity and welfare quickly return to the recent high-growth trends for China in the latter half of 2020. By September 2020, relative to September 2019, average labor productivity increased by $12.2 \%$ (equivalent to around 94 million jobs) and average welfare increased by $8.2 \%$.

In addition, we find heterogeneity in growth patterns across provinces. Provinces in eastern China returned to their normal patterns fastest-we find year-on-year labor productivity shocks of $-45.1 \%$ in February 2020 and $39.2 \%$ in September 2020. The year-on-year labor productivity in northwestern China is most stable and changed from a shock of $-23.3 \%$ in February to $23.3 \%$ in September 2020. The south-central region, where Hubei is located, recovered from a shock of $-43.8 \%$ in February 2020 to $24 \%$ in September 2020. Finally, we find that labor productivity grew faster in the second quarter when we include national trade shocks in the model than when we only use regional and sectoral value-added as output targets.

Compared with the numerous general equilibrium analyses of COVID-19 on the national level (McKibbin and Fernando 2020; Maliszewska et al. 2020; Zhang et al. 2020; Zhao 2020; Keogh-Brown et al. 2020; Sahoo and Ashwani 2020), this paper provides both a regional general equilibrium analysis and an example of using observed output data to back out regional unobserved labor productivity shocks in developing countries like China, where high-frequency regional labor productivity shocks are not readily available. Future related research can use the two full sets of labor productivity shocks.

Our model and estimates are also not without their limitations. First, the valueadded data are only for manufacturing sectors, and we do not account for agricultural sectors. However, we do not do so mainly because different administrative departments report agricultural and industrial statistics: China's Ministry of Agricultural and Rural Affairs reports agricultural statistics-for which monthly output statistics are not easily available-while the Ministry of Information and Information Technology reports industrial statistics. In addition, the current model does not consider China's bilateral trade linkages with other countries (we model China as an open economy trading with the rest of the world). Given that China's regional economies closely relate to other countries on a bilateral basis, it will be fruitful to incorporate bilateral trade linkage between China and its main trade partners in future analyses. Finally, this model does not differentiate rural and 

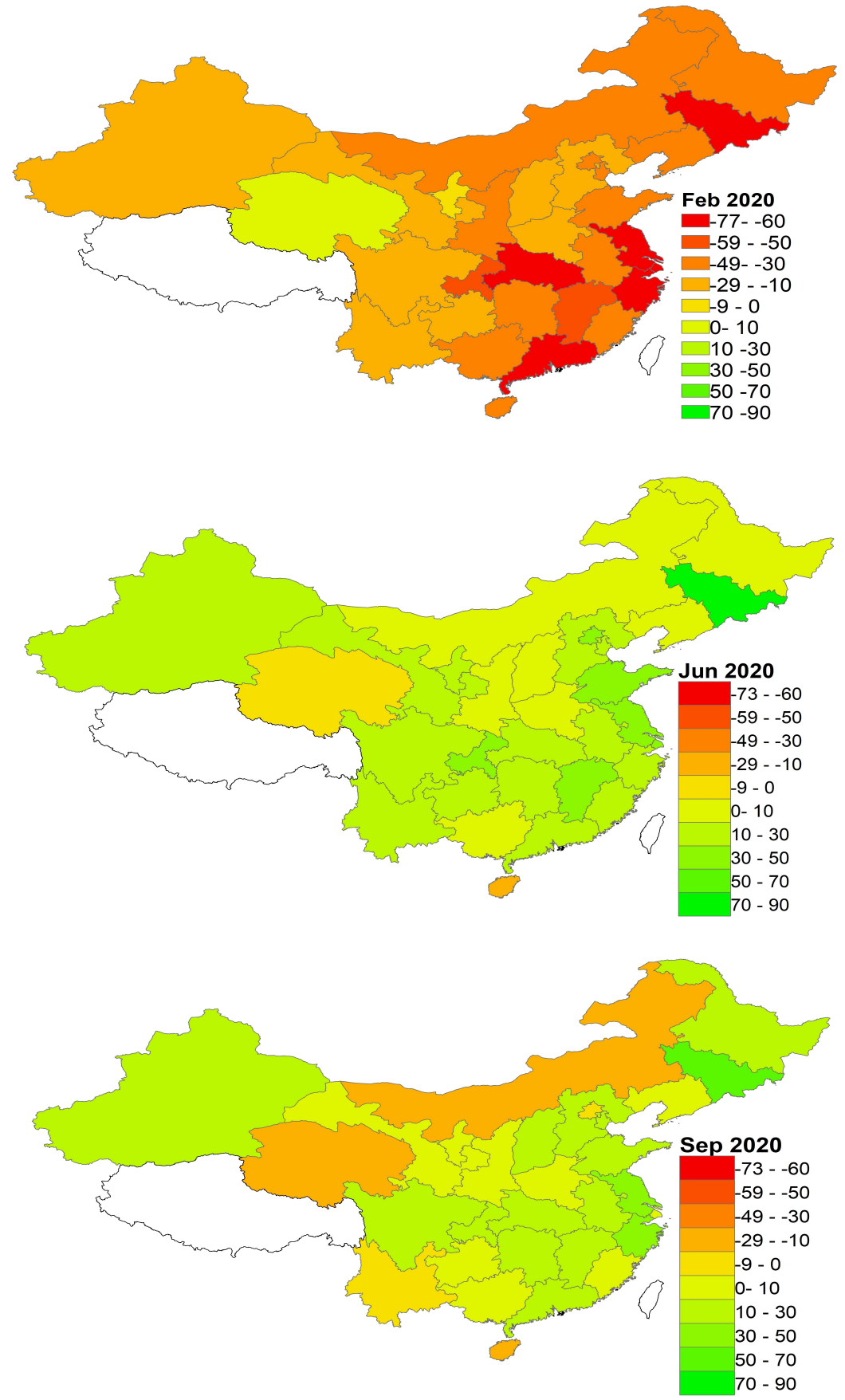

Figure 7. Labor productivity shocks in February, June, and September 2020 (\%) Note: There are no data for Tibet, Hong Kong, Macau, and Taiwan. 
urban labor and does not disaggregate households into subgroups with different income levels, which the pandemic may have impacted differently. For example, Crossley et al. (2021) find the lowest income quintiles and minority ethnic groups faced the worst labour market shocks during the pandemic in the UK. Again this would be a valuable extension for future research. 


\section{References}

Barrot JN, Grassi B, Sauvagnat J (2021) Sectoral effects of social distancing. In: AEA Papers and Proceedings, vol 111, pp 277-81

Bartik A, Bertrand M, Lin F, Rothstein J, Unrath M (2020) Measuring the labor market at the onset of the COVID-19 crisis. Tech. Rep. w27613, NBER Working Paper

Barwick PJ, Deng Y, Huang X, Li S, Li T (2020) Covid-19 pandemic and unemployment: Evidence from mobile phone data in China. Tech. rep., SSRN Working Paper http://dx.doi.org/10.2139/ssrn.3755371

Bauer A, Haltom N, Rubio-Ramirez JF (2005) Smoothing the shocks of a dynamic stochastic general equilibrium model. Economic Review (Atlanta, Ga) 90(2):3549

Bottan N, Hoffmann B, Vera-Cossio D (2020) The unequal impact of the coronavirus pandemic: Evidence from seventeen developing countries. PloS one 15(10):e0239797

Brooke A, Kendrick D, Meeraus A (1988) Gams: A user's guide. Redwood City, California, The Scientific Press Les modèles d'équilibre général calculable 821:505-528

CNBS (2020) Quarterly data statistics. Tech. rep., National Bureau Statistics of China, URL https://data.stats.gov.cn/

Crossley TF, Fisher P, Low H (2021) The heterogeneous and regressive consequences of COVID-19: Evidence from high quality panel data. Journal of Public Economics 193:104334

Dingel JI, Neiman B (2020) How many jobs can be done at home? Journal of Public Economics 189:104235

Dixon P, Rimmer MT (1998) Forecasting and policy analysis with a dynamic CGE model of Australia. Centre of Policy Studies (CoPS)

Dixon PB, Rimmer MT (2002) Dynamic general and equilibrium modelling for forecasting and policy: A practical guide and documentation of MONASH, Contributions to Economic Analysis, vol 256. Elsevier

Fang H, Wang L, Yang Y (2020) Human mobility restrictions and the spread of the novel coronavirus (2019-ncov) in china. Tech. Rep. 26906, NBER Working Paper

Ferris MC, Munson TS (2000) Complementarity problems in gams and the path solver. Journal of Economic Dynamics and Control 24(2):165188, doi:https://doi.org/10.1016/So165-1889(98)ooo92-X, URL https://www. sciencedirect.com/science/article/pii/So16518899800092X

Forsythe E, Kahn LB, Lange F, Wiczer D (2020) Labor demand in the time of COVID-19: Evidence from vacancy postings and UI claims. Journal of Public Economics 189:104238

Giesecke JA, Madden JR (2013) Regional computable general equilibrium modeling. In: Handbook of computable general equilibrium modeling, vol 1, Elsevier, pp $379-475$ 
He X, Xiong T, Zhang W (2020) CARD COVID-19 economic database: China. Tech. rep., Center for Agriculture and Rural Development, URL https://www.card. iastate.edu/china/covid-19/, accessed: 12/13/2020

IMF (2021) World economic outlook:policy support and vaccines expected to lift activity. URL https://www.imf.org/en/Publications/WEO/Issues/2021/o1/ 26/2021-world-economic-outlook-update

Keogh-Brown MR, Jensen HT, Edmunds WJ, Smith RD (2020) The impact of Covid-19, associated behaviours and policies on the UK economy: A computable general equilibrium model. SSM-population health 12:100651

Lanz B, Rutherford T (2016) Gtapingams: Multiregional and small open economy models. Journal of Global Economic Analysis 1(2):1-77

Maliszewska M, Mattoo A, Van Der Mensbrugghe D (2020) The potential impact of covid-19 on GDP and trade: A preliminary assessment. Tech. Rep. 9211, Policy Research Working Paper, the World Bank

Mathiesen L (1985) Computational experience in solving equilibrium models by a sequence of linear complementarity problems. Operations Research 33(6):12251250, doi:10.1287/opre.33.6.1225, URL https://doi.org/10.1287/opre.33.6.1225

McKibbin WJ, Fernando R (2020) The global macroeconomic impacts of COVID19: Seven scenarios. Tech. Rep. 19/2020, CAMA Working Paper

Mi Z, Meng J, Zheng H, Shan Y, Wei YM, Guan D (2018) A multi-regional inputoutput table mapping China's economic outputs and interdependencies in 2012. Scientific Data 5:180155

Modrego F, Canales A, Bahamonde H (2020) Employment effects of COVID-19 across Chilean regions: An application of the translog cost function. Regional Science Policy \& Practice 12(6):1151-1167

Monte F, Redding SJ, Rossi-Hansberg E (2018) Commuting, migration, and local employment elasticities. American Economic Review 108(12):3855-90

Porsse AA, de Souza KB, Carvalho TS, Vale VA (2020) The economic impacts of COVID-19 in Brazil based on an interregional CGE approach. Regional Science Policy \& Practice 12:1105-1121

Rutherford TF (1999) Applied general equilibrium modeling with MPSGE as a GAMS subsystem: An overview of the modeling framework and syntax. Computational Economics 14(1-2):1-46

Sahoo P, Ashwani (2020) COVID-19 and Indian economy: Impact on growth, manufacturing, trade and MSME sector. Global Business Review 69:253-264

Walmsley T, Rose A, Wei D (2021) The impacts of the coronavirus on the economy of the United States. Economics of disasters and climate change 5(1):1-52

Zhang Y, Diao X, Chen KZ, Robinson S, Fan S (2020) Impact of COVID-19 on China's macroeconomy and agri-food system-an economy-wide multiplier model analysis. China Agricultural Economic Review 12(3):387-407

Zhao B (2020) COVID-19 pandemic, health risks, and economic consequences: Evidence from China. China Economic Review 64:101561 


\section{Appendix.}

Figure A.1 illustrates China's provinces and regional classifications. Tables A.1 and A.2 provide the full set of COVID-19's monthly labor productivity impact for 30 provinces in the context of a general equilibrium trade model. Tables A.3 and A.4 provide the corresponding monthly welfare shocks for the 30 provinces.

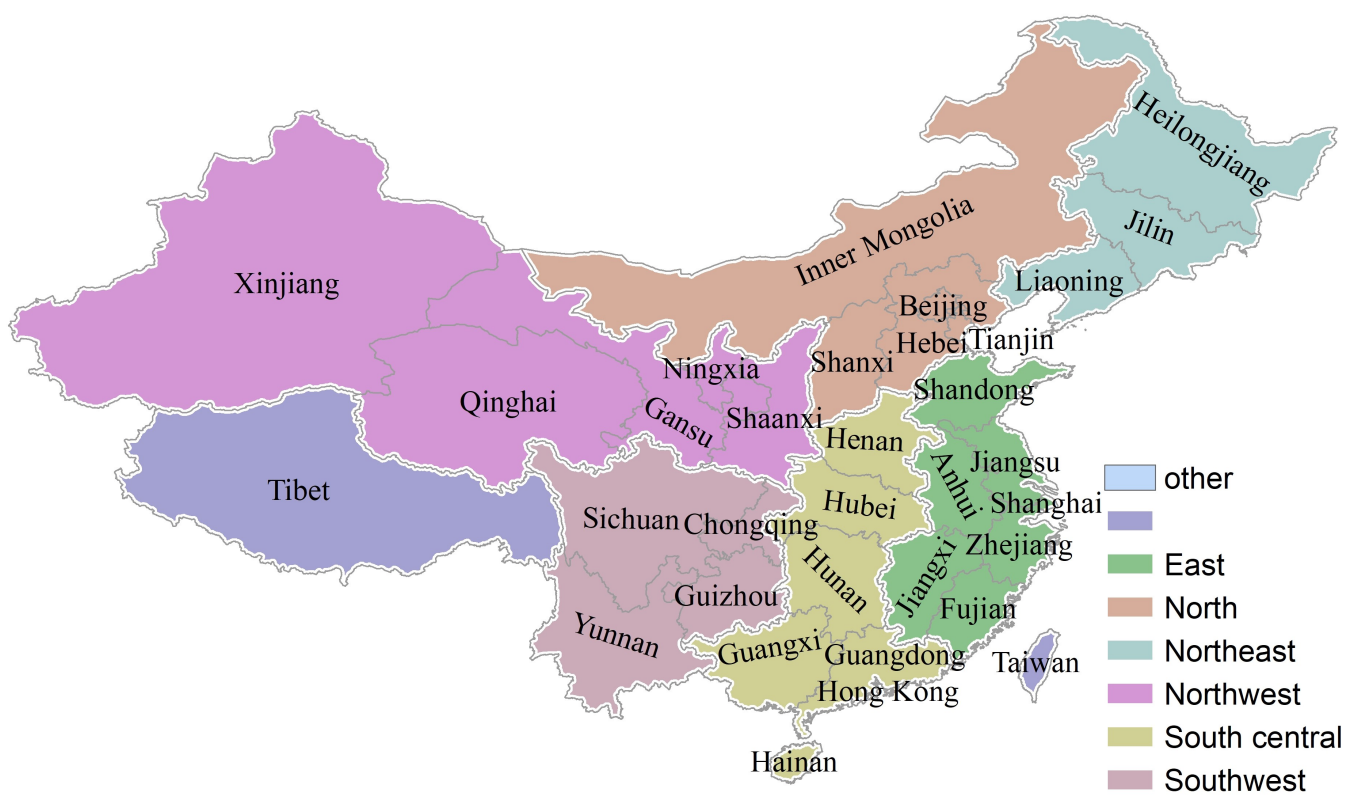

Figure A.1. China's provinces and regional classifications 
Table A.1. Calculated year-on-year labor productivity shocks in observed sectoral and provincial value-added targets (\%)

\begin{tabular}{|c|c|c|c|c|c|c|c|c|c|c|c|c|}
\hline Provinces & Region & 2019 GDP* & Nov 19 & Dec 19 & Feb 20 & Mar 20 & Apr 20 & May 20 & Jun 20 & Jul 20 & Aug 20 & Sep 20 \\
\hline Guangdong & South-central & 1563.7 & 23.9 & 18.9 & $-53 \cdot 5$ & -16.7 & 12.9 & $4 \cdot 3$ & 9.1 & 28.2 & 30.9 & 39.0 \\
\hline Jiangsu & East & 1428.6 & 31.1 & 24.8 & -46.0 & $4 \cdot 7$ & 26.9 & 25.1 & 19.2 & 19.5 & 32.4 & $44 \cdot 5$ \\
\hline Shandong & East & 1021.4 & 20.5 & $9 \cdot 5$ & -42.9 & -3.6 & $17 \cdot 4$ & 21.2 & $17 \cdot 5$ & 19.6 & 36.9 & 42.0 \\
\hline Zhejiang & East & 904.4 & 32.9 & 21.3 & $-57 \cdot 3$ & -8.5 & 31.9 & 32.3 & 14.2 & 18.4 & 36.0 & 42.8 \\
\hline Henan & South-central & 777.8 & 22.8 & 13.8 & -30.4 & 2.9 & 16.5 & 17.0 & 8.7 & -2.5 & 8.4 & 13.6 \\
\hline Sichuan & Southwest & 671.3 & $25 \cdot 4$ & $19 \cdot 3$ & -22.7 & 7.2 & 18.7 & 17.2 & 11.1 & 15.0 & $15 \cdot 4$ & 26.7 \\
\hline Hubei & South-central & 657.8 & 16.6 & 15.1 & -74.1 & -72.9 & -2.2 & $7 \cdot 3$ & 2.7 & 7.2 & 13.9 & 19.4 \\
\hline Fujian & East & 612.9 & $24 \cdot 5$ & 16.6 & $-38 \cdot 3$ & 0.8 & $13 \cdot 3$ & 16.8 & 10.6 & 15.9 & 16.8 & $23 \cdot 5$ \\
\hline Hunan & South-central & $577 \cdot 7$ & $25 \cdot 5$ & $17 \cdot 9$ & -25.6 & $7 \cdot 2$ & 16.7 & 12.1 & 11.0 & $15 \cdot 3$ & 19.5 & 23.8 \\
\hline Shanghai & East & 550.1 & 23.1 & $35 \cdot 3$ & -60.6 & -40.0 & 14.9 & 12.0 & 12.0 & 51.0 & 37.6 & 41.8 \\
\hline Anhui & East & $533 \cdot 5$ & 19.8 & 16.5 & -33.1 & 12.6 & 26.8 & 23.1 & 16.1 & 12.8 & $24 \cdot 9$ & 28.3 \\
\hline Beijing & North & 513.2 & 8.0 & 10.5 & -43.9 & $-34 \cdot 4$ & 14.9 & 14.8 & $25 \cdot 4$ & 31.6 & 20.5 & 22.1 \\
\hline Hebei & North & 506.5 & $7 \cdot 3$ & 11.0 & -25.0 & 2.3 & 13.1 & 16.9 & 5.6 & 14.7 & 16.9 & 19.7 \\
\hline Shaanxi & Northwest & 373.5 & 19.5 & 21.9 & -33.2 & $5 \cdot 9$ & 18.5 & 26.5 & -1.6 & 2.0 & 22.8 & 18.1 \\
\hline Liaoning & Northeast & 359.9 & 20.9 & 10.5 & -28.1 & -25.0 & 6.6 & 15.4 & 4.6 & 14.1 & 13.8 & 18.4 \\
\hline Jiangxi & East & 357.2 & $47 \cdot 0$ & 28.1 & $-47 \cdot 4$ & 24.2 & 32.9 & 25.0 & 27.1 & 31.3 & $34 \cdot 5$ & 46.3 \\
\hline Chongqing & Southwest & 341.8 & 27.1 & 21.9 & -54.8 & 11.4 & 28.2 & 29.5 & 28.2 & 40.9 & 36.1 & $37 \cdot 3$ \\
\hline Yunnan & Southwest & 336.3 & -19.1 & -22.0 & -42.3 & -9.2 & 0.2 & 43.8 & 29.6 & $34 \cdot 4$ & 43.6 & 28.8 \\
\hline Guangxi & South-central & $307 \cdot 5$ & 25.8 & 12.8 & $-37 \cdot 4$ & -7.6 & 5.6 & $17 \cdot 3$ & 5.6 & $15 \cdot 7$ & 15.1 & 18.9 \\
\hline $\begin{array}{l}\text { Inner Mongo- } \\
\text { lia }\end{array}$ & North & 249.2 & 5.6 & -0.8 & -27.0 & -5.8 & 6.5 & -8.5 & 1.8 & 0.6 & 6.0 & 3.8 \\
\hline Shanxi & North & 245.6 & 13.9 & 2.6 & $-34 \cdot 5$ & 22.1 & 5.0 & 6.2 & 9.6 & 16.2 & 37.6 & 52.7 \\
\hline Guizhou & Southwest & 242.8 & 22.5 & 32.3 & $-33 \cdot 7$ & $27 \cdot 9$ & 10.3 & 12.2 & 14.8 & 20.0 & $14 \cdot 3$ & 25.0 \\
\hline Tianjin & North & $203 \cdot 5$ & 30.3 & 13.6 & -46.9 & $-43 \cdot 3$ & -2.0 & 22.8 & 14.6 & $47 \cdot 1$ & 36.3 & 42.6 \\
\hline Xinjiang & Northwest & 196.9 & 11.6 & $3 \cdot 4$ & -14.7 & 11.8 & 19.9 & 27.1 & 29.8 & $15 \cdot 3$ & 12.3 & 36.5 \\
\hline
\end{tabular}


Table A.1. Calculated year-on-year labor productivity shocks in observed sectoral and provincial value-added targets (\%)

\begin{tabular}{|c|c|c|c|c|c|c|c|c|c|c|c|c|}
\hline Provinces & Region & 2019 GDP* $^{*}$ & Nov 19 & Dec 19 & Feb 20 & Mar 20 & Apr 20 & May 20 & Jun 20 & Jul 20 & Aug 20 & Sep 20 \\
\hline Heilongjiang & Northeast & 196.1 & 1.6 & 23.6 & $-41 \cdot 3$ & -19.8 & $13 \cdot 4$ & $5 \cdot 7$ & -2.3 & 0.0 & 36.4 & 42.6 \\
\hline Jilin & Northeast & 169.8 & 49.0 & 51.1 & -63.9 & -22.4 & 17.2 & 58.1 & $74 \cdot 4$ & 48.2 & 42.7 & 85.7 \\
\hline Gansu & Northwest & 126.2 & 31.4 & 19.6 & -20.6 & -18.3 & 26.6 & 45.1 & 19.9 & 21.1 & 32.1 & $24 \cdot 7$ \\
\hline Hainan & South-central & 77.2 & $19 \cdot 4$ & 20.9 & $-37 \cdot 5$ & -20.2 & -7.9 & -12.6 & $-14 \cdot 4$ & 13.0 & $5 \cdot 3$ & 5.0 \\
\hline Ningxia & Northwest & $54 \cdot 3$ & 18.0 & 28.2 & -9.5 & 26.4 & 21.0 & 11.4 & 17.2 & -32.3 & $9 \cdot 4$ & $17 \cdot 4$ \\
\hline Qinghai & Northwest & 42.6 & 40.6 & 38.6 & $-24 \cdot 5$ & $25 \cdot 7$ & 12.7 & 16.1 & $9 \cdot 5$ & 18.2 & 23.0 & 2.4 \\
\hline & East & 5408.1 & $27 \cdot 7$ & 19.5 & -45.1 & 1.2 & 24.0 & $23 \cdot 3$ & $17 \cdot 3$ & 21.2 & 31.9 & 39.2 \\
\hline & South-central & 3961.7 & 23.0 & 16.2 & -43.8 & -15.1 & 10.8 & 10.4 & $7 \cdot 4$ & $13 \cdot 5$ & 18.4 & 24.0 \\
\hline & North & 1718.1 & 10.6 & $7 \cdot 7$ & -31.6 & -3.2 & $9 \cdot 3$ & 11.2 & 9.1 & 17.9 & 21.9 & 26.7 \\
\hline & Southwest & 1592.3 & $14 \cdot 3$ & 12.1 & $-34 \cdot 5$ & 7.6 & 14.2 & 24.7 & 18.9 & 24.7 & $25 \cdot 3$ & 28.6 \\
\hline & Northeast & 1275.9 & 17.8 & 21.1 & -34.9 & -18.9 & 9.8 & 19.0 & 16.4 & 14.8 & 24.2 & 36.5 \\
\hline & Northwest & $793 \cdot 5$ & 21.8 & 18.2 & $-23 \cdot 3$ & $3 \cdot 7$ & 20.7 & 29.8 & $13 \cdot 5$ & 8.8 & 21.7 & $23 \cdot 3$ \\
\hline Average & & $473 \cdot 3$ & 21.2 & 17.6 & $-37 \cdot 9$ & -5.0 & 14.6 & 18.9 & $14 \cdot 3$ & 18.1 & $24 \cdot 3$ & 29.8 \\
\hline
\end{tabular}

Note: This table presents calculated year-on-year labor productivity shocks across 30 provinces from November 2019 to September 2020 using only value-added targets in the modeling. Please note that China's National Bureau of Statistics does not report year-on-year growth rate of value-added in January, and the productivity shocks in February denote the productivity shocks from January to February. Labor productivity shocks in regions are population-weighted average labor productivity shocks across provinces in a region.

${ }^{*}$ GDP is measured in \$US billion. 
Table A.2. Calculated year-on-year labor productivity shocks in observed sectoral and provincial value-added and national trade targets $(\%)$

\begin{tabular}{|c|c|c|c|c|c|c|c|c|c|c|c|c|}
\hline Provinces & Region & 2019 GDP* & Nov 19 & Dec 19 & Feb 20 & Mar 20 & Apr 20 & May 20 & Jun 20 & Jul 20 & Aug 20 & Sep 20 \\
\hline Guangdong & South-central & 1563.7 & 11.1 & 20.9 & -64.0 & -8.5 & -9.0 & -18.7 & 27.2 & 33.6 & 14.8 & 13.6 \\
\hline Jiangsu & East & 1428.6 & 19.0 & 12.1 & -60.3 & $9 \cdot 3$ & 26.2 & 22.4 & 42.2 & 32.6 & 32.5 & 37.6 \\
\hline Shandong & East & 1021.4 & 12.7 & 10.8 & -49.8 & $5 \cdot 7$ & 36.5 & 38.1 & 30.4 & 22.8 & $25 \cdot 3$ & 25.8 \\
\hline Zhejiang & East & $904 \cdot 4$ & 23.0 & 16.8 & -66.0 & -0.8 & 45.8 & 43.6 & 28.9 & $25 \cdot 3$ & 30.3 & 31.8 \\
\hline Henan & South-central & 777.8 & 19.7 & 22.8 & -28.4 & $7 \cdot 7$ & 7.8 & $5 \cdot 4$ & 8.4 & -6.7 & -2.3 & 0.9 \\
\hline Sichuan & Southwest & 671.3 & 18.6 & 21.9 & -29.7 & 12.5 & 12.2 & 8.7 & 19.1 & 16.0 & 7.0 & 14.2 \\
\hline Hubei & South-central & 657.8 & 11.3 & 13.2 & -76.8 & -72.0 & $3 \cdot 3$ & 12.3 & 11.0 & 10.7 & 10.4 & 13.6 \\
\hline Fujian & East & 612.9 & 16.9 & 20.3 & -47.1 & 8.7 & 8.8 & 8.8 & 19.8 & $17 \cdot 3$ & $5 \cdot 9$ & 7.8 \\
\hline Hunan & South-central & $577 \cdot 7$ & 19.9 & 19.5 & -30.8 & 12.5 & 16.5 & 10.5 & 18.2 & 16.5 & 12.4 & 13.9 \\
\hline Shanghai & East & 550.1 & 9.6 & $43 \cdot 5$ & -68.8 & -31.5 & -5.2 & -11.1 & 33.6 & 54.8 & 14.4 & 9.9 \\
\hline Anhui & East & $533 \cdot 5$ & $15 \cdot 3$ & 19.1 & -37.1 & $17 \cdot 9$ & 27.6 & 21.6 & 21.1 & 12.9 & $17 \cdot 3$ & 18.4 \\
\hline Beijing & North & 513.2 & 0.7 & 18.9 & $-49 \cdot 5$ & -26.1 & 12.5 & $7 \cdot 9$ & 41.6 & 32.0 & 3.1 & -0.1 \\
\hline Hebei & North & 506.5 & $3 \cdot 5$ & 12.6 & -29.4 & 6.9 & 14.5 & 16.1 & 12.2 & 16.1 & 11.0 & 11.5 \\
\hline Shaanxi & Northwest & $373 \cdot 5$ & 15.6 & 31.5 & -32.0 & 14.7 & 19.5 & 22.6 & 1.0 & -1.6 & 9.6 & $3 \cdot 3$ \\
\hline Liaoning & Northeast & 359.9 & 16.7 & 13.5 & -32.1 & -21.2 & 8.6 & 16.1 & $9 \cdot 5$ & 13.9 & 6.8 & $9 \cdot 4$ \\
\hline Jiangxi & East & 357.2 & 31.5 & 29.6 & -55.8 & 35.2 & $23 \cdot 4$ & 12.5 & 44.0 & $35 \cdot 5$ & 18.5 & 21.2 \\
\hline Chongqing & Southwest & 341.8 & 21.3 & $25 \cdot 5$ & -58.2 & 17.0 & 23.9 & 24.1 & $35 \cdot 7$ & $39 \cdot 7$ & 26.3 & $25 \cdot 4$ \\
\hline Yunnan & Southwest & 336.3 & -19.2 & 1.7 & -28.2 & -0.1 & -24.8 & 6.8 & $15 \cdot 5$ & 13.0 & 10.2 & -4.1 \\
\hline Guangxi & South-central & 307.5 & 21.4 & 23.6 & $-37 \cdot 4$ & -1.2 & -2.4 & 6.2 & 5.9 & 10.0 & 0.9 & 2.2 \\
\hline $\begin{array}{l}\text { Inner Mongo- } \\
\text { lia }\end{array}$ & North & 249.2 & -0.3 & 8.2 & -30.1 & $5 \cdot 3$ & 11.5 & $-7 \cdot 9$ & 8.7 & -1.5 & -9.0 & -14.0 \\
\hline Shanxi & North & 245.6 & 12.2 & 17.8 & -26.0 & 30.7 & -1.1 & $-3 \cdot 5$ & $5 \cdot 7$ & 6.1 & 17.9 & 29.5 \\
\hline Guizhou & Southwest & 242.8 & 18.9 & 47.8 & -29.9 & $37 \cdot 7$ & 2.1 & 0.9 & 13.4 & 12.1 & -1.6 & $5 \cdot 7$ \\
\hline Tianjin & North & 203.5 & $23 \cdot 5$ & 22.9 & -49.9 & -38.3 & -11.0 & $7 \cdot 5$ & 22.5 & 44.0 & 18.9 & 20.5 \\
\hline
\end{tabular}


Table A.2. Calculated year-on-year labor productivity shocks in observed sectoral and provincial value-added and national trade targets $(\%)$

\begin{tabular}{|c|c|c|c|c|c|c|c|c|c|c|c|c|}
\hline Provinces & Region & 2019 GDP* & Nov 19 & Dec 19 & Feb 20 & Mar 20 & Apr 20 & May 20 & Jun 20 & Jul 20 & Aug 20 & Sep 20 \\
\hline Xinjiang & Northwest & 196.9 & 9.4 & 17.9 & -10.0 & 20.8 & 12.7 & $15 \cdot 5$ & 27.2 & 6.3 & -4.6 & 14.6 \\
\hline Heilongjiang & Northeast & 196.1 & $-3 \cdot 4$ & 34.6 & -42.1 & -12.0 & 13.7 & 1.6 & 2.3 & -3.2 & 18.4 & 20.1 \\
\hline Jilin & Northeast & 169.8 & 46.0 & 68.2 & -60.9 & -16.4 & 20.1 & 62.2 & 72.1 & $35 \cdot 7$ & 25.9 & 65.4 \\
\hline Gansu & Northwest & 126.2 & 27.9 & 36.0 & -15.0 & -11.9 & 13.1 & 25.2 & 16.9 & 11.7 & 11.9 & $3 \cdot 5$ \\
\hline Hainan & South-central & 77.2 & 13.1 & $33 \cdot 5$ & -38.0 & -12.3 & -15.8 & -24.1 & -12.2 & $7 \cdot 7$ & -11.1 & $-14 \cdot 3$ \\
\hline Ningxia & Northwest & $54 \cdot 3$ & 16.3 & 40.4 & $-3 \cdot 3$ & 33.6 & 12.4 & 1.8 & 13.9 & -36.8 & -2.0 & 4.2 \\
\hline \multirow[t]{7}{*}{ Qinghai } & Northwest & 42.6 & 42.5 & 85.8 & 0.8 & 40.1 & -15.2 & -18.9 & -9.4 & -7.2 & -10.9 & -26.8 \\
\hline & East & 5408.1 & 18.1 & 18.1 & -53.7 & 8.8 & 27.9 & 24.7 & 31.8 & 26.3 & 22.9 & 24.6 \\
\hline & South-central & 3961.7 & 16.1 & 20.6 & -47.6 & -9.6 & 2.0 & -0.2 & 15.1 & 13.9 & 7.2 & 8.5 \\
\hline & North & 1718.1 & 6.2 & 14.8 & -33.1 & 3.7 & 8.3 & 6.7 & 14.8 & 15.9 & $9 \cdot 3$ & 11.0 \\
\hline & Southwest & 1592.3 & 9.9 & 22.2 & -33.8 & 14.7 & 3.2 & 9.2 & 19.8 & 18.3 & $9 \cdot 3$ & 10.0 \\
\hline & Northeast & 1275.9 & 14.2 & 28.9 & -35.8 & -14.1 & 11.1 & 18.9 & 18.9 & 11.2 & 13.0 & 22.7 \\
\hline & Northwest & 793.5 & 18.9 & 33.1 & -18.4 & 12.1 & $13 \cdot 7$ & 17.7 & 11.7 & 1.0 & 4.7 & $4 \cdot 4$ \\
\hline Average & & $473 \cdot 3$ & 15.8 & 26.4 & -39.5 & 2.1 & 9.6 & 10.5 & 19.5 & 15.6 & 10.3 & 12.2 \\
\hline
\end{tabular}

Note: This table presents calculated year-on-year labor productivity shocks across 30 provinces from November 2019 to September 2020 using both value-added and trade series in the modeling. The provinces and regions are ordered based on their GDP in 2019 (\$US billion). Please note that the China's National Bureau of Statistics does not report growth rate of value-added in January, and the productivity shocks in February denote the productivity shocks from January to February. Labor productivity shocks in regions are population-weighted average labor productivity shocks across provinces in a region.

*GDP is measured in \$US billion. 
Table A.3. Calculated year-on-year welfare changes in observed sectoral and provincial value-added targets (\%)

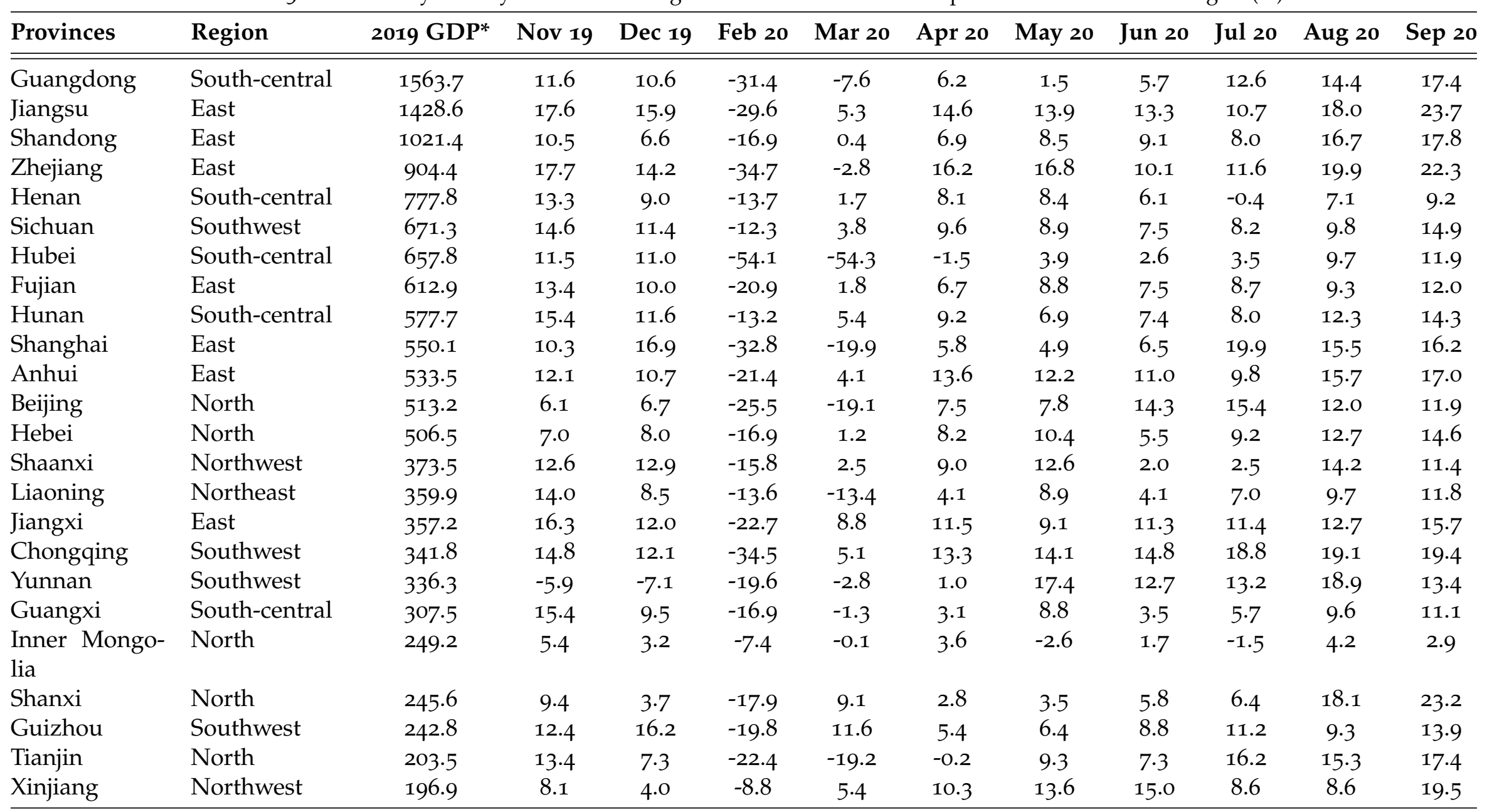


Table A.3. Calculated year-on-year welfare changes in observed sectoral and provincial value-added targets (\%)

\begin{tabular}{|c|c|c|c|c|c|c|c|c|c|c|c|c|}
\hline Provinces & Region & 2019 GDP* & Nov 19 & Dec 19 & Feb 20 & Mar 20 & Apr 20 & May 20 & Jun 20 & Jul 20 & Aug 20 & Sep 20 \\
\hline Jilin & Northeast & 169.8 & 16.8 & $17 \cdot 7$ & -28.6 & $-7 \cdot 7$ & 6.4 & $17 \cdot 5$ & 21.6 & 13.7 & 15.2 & 26.0 \\
\hline Hainan & South-central & 77.2 & 10.4 & 10.7 & -17.4 & -9.1 & -2.9 & $-4 \cdot 7$ & -4.2 & 6.2 & 4.8 & 3.9 \\
\hline Ningxia & Northwest & $54 \cdot 3$ & 12.0 & 16.3 & -8.9 & 11.1 & 11.1 & 6.5 & 11.1 & -15.6 & 8.6 & 12.5 \\
\hline \multirow[t]{5}{*}{ Qinghai } & Northwest & 42.6 & 14.1 & 12.7 & -13.6 & 6.1 & 4.8 & 6.0 & $4 \cdot 5$ & $7 \cdot 7$ & 10.0 & 4.2 \\
\hline & North & 1718.1 & 6.2 & 8.1 & -18.1 & -0.7 & 5.6 & 6.7 & 7.8 & 8.5 & 11.0 & 12.6 \\
\hline & Southwest & 1592.3 & $7 \cdot 4$ & 10.1 & -19.0 & $5 \cdot 3$ & $7 \cdot 4$ & 11.4 & 11.7 & 11.1 & 11.1 & 12.7 \\
\hline & Northeast & 1275.9 & 8.3 & 12.2 & -16.5 & $-7 \cdot 5$ & $4 \cdot 5$ & $7 \cdot 7$ & 7.9 & $5 \cdot 7$ & 10.0 & $13 \cdot 3$ \\
\hline & Northwest & 793.5 & 11.5 & $13 \cdot 3$ & -12.6 & 2.0 & 10.3 & 14.2 & 10.5 & $5 \cdot 7$ & 11.7 & 11.9 \\
\hline Average & & $473 \cdot 3$ & 11.7 & 10.1 & -20.8 & -3.1 & 7.1 & 8.8 & 8.0 & 8.3 & 12.8 & 14.7 \\
\hline
\end{tabular}

Note: This table presents calculated year-on-year welfare changes across 30 provinces from November 2019 to September 2020 using only value-added targets in the modeling. The provinces and regions are ordered based on their GDP in 2019 (\$US billion). Please note that the China's National Bureau of Statistics does not report growth rate of value-added in January, and the productivity shocks in February denote the productivity shocks from January to February. Welfare shocks in regions are population-weighted average welfare shocks across provinces in a region.

${ }^{*} \mathrm{GDP}$ is measured in $\$ \mathrm{US}$ billion. 
Table A.4. Calculated year-on-year welfare changes in observed sectoral and provincial value-added and national trade targets (\%)

\begin{tabular}{|c|c|c|c|c|c|c|c|c|c|c|c|c|}
\hline Provinces & Region & 2019 GDP* & Nov 19 & Dec 19 & Feb 20 & Mar 20 & Apr 20 & May 20 & Jun 20 & Jul 20 & Aug 20 & Sep 20 \\
\hline Guangdong & South-central & 1563.7 & 8.2 & 16.8 & -31.9 & $-3 \cdot 4$ & -4.4 & -10.7 & $7 \cdot 3$ & 9.9 & 4.5 & 4.8 \\
\hline Jiangsu & East & 1428.6 & 18.2 & 36.1 & -14.1 & 11.5 & -8.3 & -13.8 & 0.0 & -6.0 & -3.8 & 0.8 \\
\hline Shandong & East & 1021.4 & 8.0 & 11.7 & -17.1 & 4.6 & $5 \cdot 7$ & 6.2 & 10.2 & 5.6 & 8.6 & 8.0 \\
\hline Zhejiang & East & 904.4 & 16.8 & $27 \cdot 7$ & $-27 \cdot 4$ & 3.0 & $5 \cdot 5$ & 2.8 & $3 \cdot 9$ & 1.7 & $4 \cdot 4$ & 5.6 \\
\hline Henan & South-central & 777.8 & 8.6 & $3 \cdot 3$ & -25.6 & 3.8 & 12.6 & 13.4 & 16.0 & 5.8 & $7 \cdot 9$ & $7 \cdot 5$ \\
\hline Sichuan & Southwest & 671.3 & 11.2 & 13.6 & -16.5 & $7 \cdot 2$ & $7 \cdot 2$ & $5 \cdot 7$ & 11.1 & 8.1 & $4 \cdot 4$ & $7 \cdot 5$ \\
\hline Hubei & South-central & 657.8 & 8.8 & 12.9 & -54.8 & -52.9 & -2.5 & 2.0 & 5.6 & $3 \cdot 5$ & 4.9 & $5 \cdot 4$ \\
\hline Fujian & East & 612.9 & 10.7 & 11.9 & -24.9 & 5.0 & $5 \cdot 9$ & $7 \cdot 0$ & 10.5 & 8.7 & 4.7 & $5 \cdot 7$ \\
\hline Hunan & South-central & $577 \cdot 7$ & 12.3 & 13.8 & -16.6 & 8.9 & $7 \cdot 7$ & $4 \cdot 4$ & 11.1 & 8.1 & 6.8 & 6.9 \\
\hline Shanghai & East & 550.1 & $7 \cdot 3$ & 23.8 & -32.6 & -16.0 & -2.1 & -4.7 & 8.4 & 16.9 & $5 \cdot 5$ & 4.1 \\
\hline Anhui & East & 533.5 & 9.6 & 14.9 & -22.5 & 8.1 & 11.3 & 8.8 & 13.1 & 8.2 & 8.7 & 8.5 \\
\hline Beijing & North & 513.2 & 3.2 & 10.7 & $-27 \cdot 7$ & -15.1 & 6.6 & $5 \cdot 5$ & 18.9 & 14.7 & 4.5 & 2.6 \\
\hline Hebei & North & 506.5 & $4 \cdot 5$ & 12.0 & -18.3 & 5.0 & 5.8 & 6.7 & 7.6 & $7 \cdot 7$ & 5.8 & 6.0 \\
\hline Shaanxi & Northwest & $373 \cdot 5$ & 8.5 & 11.0 & -23.6 & 6.0 & 12.7 & 15.8 & $9 \cdot 4$ & 6.0 & 11.6 & 6.8 \\
\hline Liaoning & Northeast & 359.9 & 11.3 & 10.8 & -16.6 & -10.5 & $3 \cdot 3$ & $7 \cdot 5$ & 7.1 & 6.8 & $4 \cdot 5$ & 5.1 \\
\hline Jiangxi & East & 357.2 & 12.9 & 16.1 & $-24 \cdot 4$ & 13.2 & $7 \cdot 5$ & 3.6 & 14.2 & 10.1 & 4.9 & 5.9 \\
\hline Chongqing & Southwest & 341.8 & 12.0 & 15.9 & $-35 \cdot 7$ & 8.9 & 11.0 & 10.8 & 17.6 & $17 \cdot 4$ & 12.4 & 11.3 \\
\hline Yunnan & Southwest & 336.3 & -10.9 & $-17 \cdot 3$ & $-35 \cdot 4$ & -0.7 & 8.3 & 26.0 & 26.1 & 22.1 & 21.0 & 12.6 \\
\hline Guangxi & South-central & 307.5 & 9.9 & 3.2 & -30.2 & 1.2 & 7.6 & 13.2 & 14.5 & 12.7 & 9.8 & 8.3 \\
\hline $\begin{array}{l}\text { Inner Mongo- } \\
\text { lia }\end{array}$ & North & 249.2 & 1.0 & 0.9 & -16.9 & $3 \cdot 5$ & 6.8 & 0.0 & 10.1 & 2.7 & 1.7 & -2.1 \\
\hline Shanxi & North & 245.6 & 5.8 & 1.2 & $-25 \cdot 3$ & 12.0 & 8.0 & 8.6 & 12.5 & 9.8 & 16.1 & 19.0 \\
\hline Guizhou & Southwest & 242.8 & 8.2 & 12.6 & -28.3 & 15.0 & 12.0 & 13.1 & 17.1 & 15.6 & 8.3 & 10.8 \\
\hline Tianjin & North & 203.5 & 9.1 & $3 \cdot 3$ & -31.8 & -17.2 & $4 \cdot 7$ & 14.2 & 16.3 & 21.4 & 14.6 & 14.5 \\
\hline
\end{tabular}


Table A.4. Calculated year-on-year welfare changes in observed sectoral and provincial value-added and national trade targets

$(\%)$

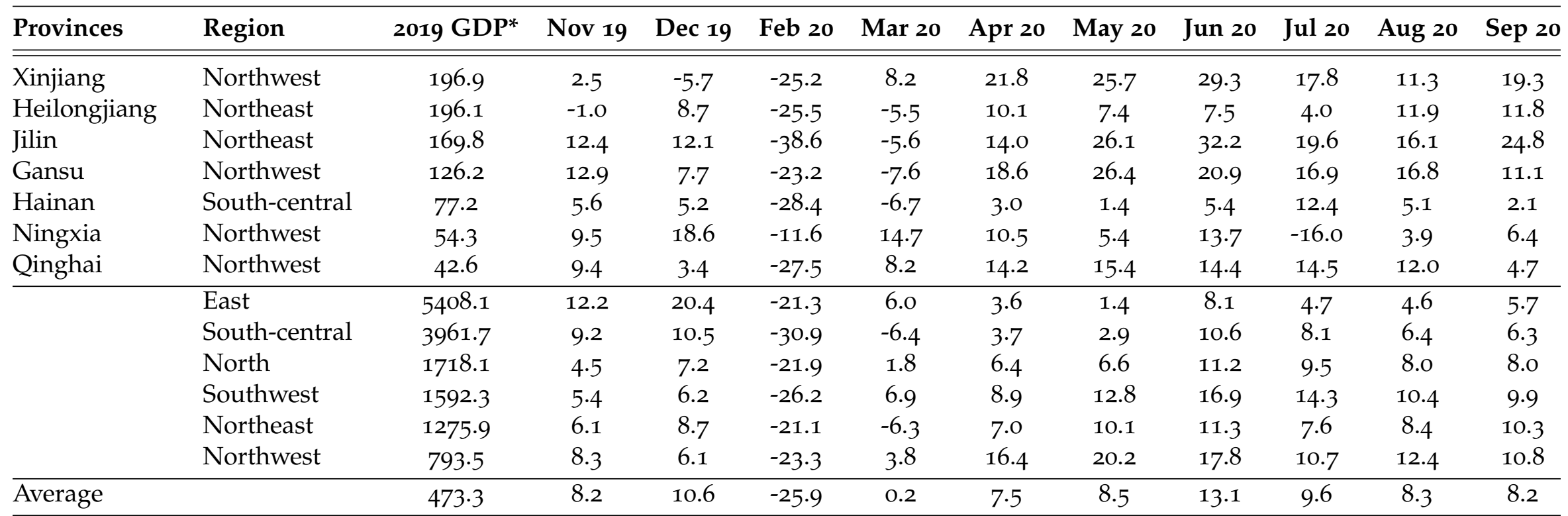

Note: This table presents calculated year-on-year welfare changes across 30 provinces from November 2019 to September 2020 using both value-added and trade series in the modeling. The provinces and regions are ordered based on their GDP in 2019 (\$US). Please note that the China's National Bureau of Statistics does not report growth rate of value-added in January, and the productivity shocks in February denote the productivity shocks from January to February. Welfare shocks in regions are population-weighted average welfare shocks across provinces in a region.

*GDP is measured in \$US billion. 